\title{
Seasonal niche strategy of the bloom-forming dinoflagellate Heterocapsa triquetra
}

\author{
R. W. Litaker ${ }^{1,2,}{ }^{*}$, P. A. Tester ${ }^{1}$, C. S. Duke ${ }^{3}$, B. E. Kenney ${ }^{4}$, J. L. Pinckney ${ }^{5}$, J. Ramus ${ }^{4}$ \\ ${ }^{1}$ Center for Coastal Fisheries and Habitat Research, National Ocean Service, NOAA, 101 Pivers Island Road, Beaufort, \\ North Carolina 28516, USA \\ ${ }^{2}$ Program in Molecular Biology \& Biotechnology, CB\#7100, 442 Taylor Hall, University of North Carolina, Chapel Hill, \\ North Carolina 27599, USA \\ ${ }^{3}$ The Environmental Company, Inc., 1611 N. Kent Street, Suite 900, Arlington, Virginia 22209, USA \\ ${ }^{4}$ Marine Laboratory, Nicholas School of the Environment and Earth Sciences, Duke University, 135 Duke Marine Lab Road, \\ Beaufort, North Carolina 28516, USA \\ ${ }^{5}$ Department of Oceanography, Texas A\&M University, Eller Oceanographic and Meteorology Building, College Station, \\ Texas 77843, USA
}

\begin{abstract}
Heterocapsa triquetra is one of the most common bloom-forming dinoflagellates found in estuaries and near shore regions around the world. This work examined the environmental factors associated with 3 separate wintertime $H$. triquetra blooms in the shallow tidally mixed Newport River estuary, North Carolina, USA. During 2 of the blooms in 1982 and 1983, the estuary was sampled from a fixed, single location every hour for $14 \mathrm{~d}$. During the third study, the estuary was sampled at 9 fixed locations over its entire length each week from late December 1997 through March 1998. This time period included the formation and decline of the $H$. triquetra bloom. Barometric pressure, precipitation, photosynthetically active radiation, salinity, temperature, nutrient concentrations, and chl a were measured in each study. During the 1997-1998 study, pigments were analyzed using HPLC to characterize the phytoplankton assemblages and the dominant dinoflagellates in each sample were counted. The prevailing environmental conditions associated with the wintertime blooms were largely the result of atmospheric forcing. Low pressure systems moved through the study area at 3 to 4 d intervals and were accompanied by low ambient air temperatures and regular rainfall. Runoff following the rainfall events supplied inorganic nutrients critical for bloom initiation and development. It also created a mesohaline frontal zone in the middle portion of the estuary with salinity and hydrodynamic conditions favorable for $H$. triquetra growth. Here, the $H$. triquetra bloom reached its maximal development with chl a levels $>100 \mu \mathrm{g} \mathrm{l}^{-1}$ and cell densities between 1 and $6 \times 10^{6} \mathrm{l}^{-1}$. As the $H$. triquetra bloom developed, nutrient inputs from the river became insufficient to meet growth demand and $H$. triquetra began feeding mixotrophically, supplementing its nutritional requirements and reducing competition from co-occurring dinoflagellates. Cloud cover associated with the low pressure systems transiently limited $H$. triquetra growth as did low temperatures. More importantly though, low temperatures limited micro- and macrozooplankton populations to such an extent that grazing losses were minimal. Hence, in order to bloom, $H$. triquetra optimizes a suite of factors including low grazing pressure, increased nutrient inputs, alternative nutrient sources, and favorable salinity and hydrodynamic conditions, as well as the negative factors of temperature-limited growth, short day lengths, and periods of transient light limitation.
\end{abstract}

KEY WORDS: Dinoflagellate blooms $\cdot$ Seasonal niche strategy $\cdot$ HPLC $\cdot$ Meteorological forcing Resale or republication not permitted without written consent of the publisher

\section{INTRODUCTION}

Heterocapsa (= Peridinium) triquetra (Ehrenberg) Stein is one of the most common bloom-forming dinoflagellates found in the coastal and estuarine waters of the

*E-mail: wayne.litaker@noaa.gov world. Regular blooms have been observed in the North Sea, the north and south Atlantic, the Mediterranean, and in the eastern Pacific (Braarud \& Pappas 1951, Braarud 1962, Marshall 1967a,b, 1980, Mulford 1972, Anderson et al. 1983, Yamochi \& Joh 1986, Marshall \& Alden 1990, Kim et al. 1990, Pierce \& Turner 1994, Kononen et al. 1999). A large dinoflagellate bloom dom- 
inated by $H$. triquetra usually occurs sometime between January and March in North Carolina estuaries (Hobbie 1971, Hobbie et al. 1972, Campbell 1973, Kuenzler et al. 1979, Lapennas 1980, Lee et al. 1990, Rudek et al. 1991). These blooms generally begin as a mixture of different dinoflagellate species, but rapidly become dominated by $H$. triquetra. At the height of these blooms, $H$. triquetra chl a levels typically exceed $150 \mu \mathrm{g} \mathrm{l}^{-1}$ and can account for up to one-half of the annual phytoplankton carbon production in North Carolina estuaries (Paerl et al. 1998, Pinckney et al. 1998). The occurrence of these highly productive winter blooms is somewhat surprising because they develop when water temperatures are at, or near, the annual minimum and incident light fluxes are low compared with other times of the year (Litaker et al. 2002, this volume).

To better understand how Heterocapsa triquetra exploits the wintertime environment, we sampled the Newport River estuary, North Carolina $\left(34^{\circ} 45^{\prime} \mathrm{N}\right.$, $76^{\circ} 40^{\prime} \mathrm{W}$ ) during 3 different winter blooms. In the first 2 studies, the middle portion of the estuary was sampled time-intensively, every $\mathrm{h}$ for $2 \mathrm{wk}$, from a single station during February 1982 and February 1983. In the third study, samples were taken weekly from late December 1997 through the end of March 1998 at 9 stations along the length of the estuary. The physical, chemical, and biological factors associated with bloom formation were measured. Despite suboptimal temperatures and light levels, $H$. triquetra was able to utilize the prevailing nutrient and salinity conditions, and low grazing environment, to bloom during January and February.

\section{MATERIALS AND METHODS}

Time-intensive studies (1982 and 1983). The Newport River estuary, North Carolina, is a shallow (ca. $1 \mathrm{~m}$ depth), well-mixed estuary covering $27 \mathrm{~km}^{2}$ (Litaker et al. 1987). During this study, a station located in the geographic middle of the estuary was monitored hourly from 11 to 25 February 1982 and from 30 January to 13 February 1983 (Stn 7 in Fig. 1). These 2 studies spanned the period when Heterocapsa triquetra blooms regularly occur in the Newport River estuary. Basin residence times for water near the sampling station ranged from 7 to $45 \mathrm{~d}$, longer than for the narrower oligohaline upper estuary and the higher salinity, tidally flushed lower estuary (Hyle 1976).

Salinity (psu) as conductivity and water temperature were determined using an Industrial Instruments RS-52 salinometer. Photosynthetically active radiation (PAR, $\mu \mathrm{E} \mathrm{m}^{-2} \mathrm{~s}^{-1}$ ) was determined with a Li-Cor 192S sensor attached to a recording integrator. Secchi depth (SD) was measured using a $0.3 \mathrm{~m}$ Secchi disk attached to a calibrated pole. Attenuation coefficients $(k)$ were calculated empirically from the simultaneous SD and light attenuation measurements. The relationship was found to be $k=1.35 / \mathrm{SD}$. Cumulative daily PAR was determined by summing the average hourly water column fluxes (Riley 1957). Residual $\mathrm{NO}_{3}^{-}, \mathrm{NO}_{2}^{-}$, and $\mathrm{PO}_{4}^{-}{ }_{4}^{3}$ were measured using a Technicon II autoanalyzer. $\mathrm{NH}_{4}^{+}$was measured using the phenol hypochlorite method (Koroleff 1970). Chl a ( $\left.\mu \mathrm{g} \mathrm{l}^{-1}\right)$ was determined by fluorometric analysis (Turner Design III fluorometer) of particulate material collected by gentle suction onto glass fiber filters (Gelman A/E) and extracted into $90 \%$ acetone (Yentsch \& Menzel 1963, Parsons et al. 1984).

Spatially intensive study (1997 to 1998). The Newport River estuary was sampled at 9 locations every week from 23 December 1997 through 27 March 1998 (Fig. 1). The 1982 and 1983 studies showed no significant vertical differences in temperature, salinity or $\mathrm{pH}$. Hence, only surface samples were collected. Temperature was measured at each station with a thermometer.

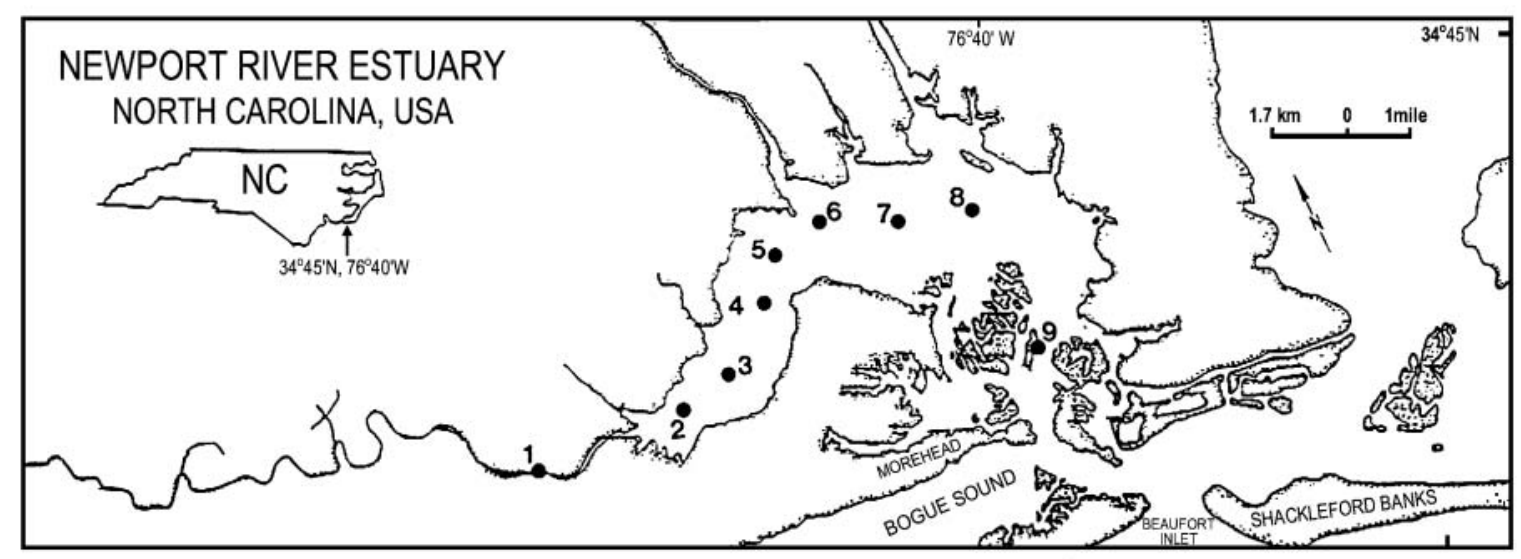

Fig. 1. Location of the Newport River estuary, North Carolina, and the various sampling sites. The fixed-point sampling station for the 1982 and 1983 studies is located at Stn 7. Stns 1 through 9 were sampled during the 23 December 1997 through 27 March 1998 study 
Salinity was determined with a model 180 Orion conductivity meter. Chl a was determined as in the timeintensive studies. For nutrient analysis, $100 \mathrm{ml}$ of water from each station was filtered through a Gelman GF/F glass fiber filter into an acid cleaned container. The filtrate was frozen immediately at $-80^{\circ} \mathrm{C}$. These nutrient samples were subsequently thawed and analyzed for $\mathrm{NO}_{3}^{-}+\mathrm{NO}_{2}^{-}, \mathrm{NH}_{4}^{+}$, and $\mathrm{PO}_{4}{ }^{3-}$ using a Model QuikChem 8000 Lachat autoanalyzer system. Samples for HPLC pigment analyses were obtained by filtering 80 to $400 \mathrm{ml}$ samples through a $45 \mathrm{~mm}$ Gelman GF/F glass fiber filter. Excess water was removed from the filters by blotting before freezing the samples at $-80^{\circ} \mathrm{C}$. The HPLC pigment profiles for each sample were determined using the methods described in Tester et al. (1995) and Pinckney et al. (1998).

Surface water samples $(\sim 125 \mathrm{ml})$ were taken at each station, preserved with Utermöhl solution (Guillard 1973), and kept tightly capped in dark bottles. A total of 103 samples was counted for the presence of the dinoflagellate Heterocapsa triquetra and the ciliate Mesodinium rubrum (= Myronecta rubra, Cyclotrichium meunieri, Halteria rubra) at either $100 \times$ or $200 \times$ using an inverted Wild microscope (Lund et al. 1958). The volumes of the sample chambers were between 2.07 and $3.03 \mathrm{ml}$. Normally half of the chamber was counted. When samples were too concentrated to allow accurate counts (>500 cells per half chamber), an aliquot was diluted $1: 3$ or $1: 10$ prior to counting. Prorocentrum minimum was also abundant from 23 January through 13 February 1998, and counts were recorded for all samples where there were $>100$ cells $\mathrm{ml}^{-1}$. At no time during this winter bloom was any other dinoflagellate species more abundant than this.

Laboratory studies have shown that Heterocapsa triquetra increases in size by approximately $60 \%$ when it switches from autotrophic growth to feeding mixotrophically on other phytoplankton species (Legrand et al. 1998). To determine if a similar size shift occurred in the field, the width and length of 100 cells were measured from the station with the highest $H$. triquetra concentrations on 16 January, 6 February, and 20 February 1998. These sampling periods were selected as representative of the pre-bloom, bloom, and bloom decline. A calibrated eyepiece micrometer was used to determine if the dimensions and volume of $H$. triquetra cells changed during the course of the bloom, indicating a switch to mixotrophic feeding. Cell volume was calculated as described in Hillebrand et al. (1999).

Net tows for zooplankton were made at the surface with a $333 \mu \mathrm{m}$ mesh ( $0.5 \mathrm{~m}$ diameter) net on 13 and 20 February 1998 to assess the abundance of macrozooplankton grazers. Three to 5 min tows were made at speeds between 0.5 to $1 \mathrm{~m} \mathrm{~s}^{-1}$. The filtered volume was calculated using a General Oceanics, Inc. flow meter
(Model 2030). On 13 February 1998, the zooplankton from 16.6 and $25.8 \mathrm{~m}^{3}$ tows was almost entirely (>95\%) Acartia tonsa. A. tonsa strongly dominated the zooplankton again on 20 February with ca. $10 \%$ of the material in the tow composed of resuspended particulate material. Zooplankton abundances (excluding gelatinous plankton) were estimated by settling the filtered plankton in volumetric cylinders. The displacement volumes of the tows were 1.0 (13 February) and $1.3 \mathrm{ml}$ (20 February). Final copepod abundance estimates were calculated using a displacement volume to dry weight conversion (Wiebe 1988) and a mean dry weight of $6.44 \mu \mathrm{g}$ adult female ${ }^{-1}$ A. tonsa (Ambler 1982).

The grazing rate of Acartia tonsa on a Heterocapsa triquetra bloom population was determined as follows. Copepods were returned to the laboratory in insulated coolers and sorted within 1 to $2 \mathrm{~h}$ of collection. They were allowed to acclimate to laboratory conditions for $24 \mathrm{~h}$ before the start of the grazing experiments. All experimental copepods were robust and actively swimming $A$. tonsa. Twenty adult female $A$. tonsa were placed in each of 5 replicate containers with 370 to $390 \mathrm{ml}$ of Newport River water with ambient concentrations of $H$. triquetra ( 5550 to 6800 cells $\mathrm{ml}^{-1}$ ). Copepods were allowed to graze in the dark for 26.18 to $26.25 \mathrm{~h}$ at 18 to $19^{\circ} \mathrm{C}$. An initial sample was fixed at $t=0$ and a control sample without copepods was maintained under the same conditions as the grazing samples to account for the growth of phytoplankton during the experiment. At the end of each experiment, the grazing containers were visually inspected to ensure that all copepods were actively swimming and then fixed in Utermöhl's solution. Aliquots of at least $2 \mathrm{ml}$ of the $H$. triquetra cells from the grazing experiments were settled in an Utermöhl chamber and counted using a Wild inverted microscope. Filtration (clearance) rates were calculated using the equations of Frost (1972).

Microzooplankton abundances were estimated by settling $25 \mathrm{ml}$ of Utermöhl preserved material and counting the number of ciliates at $100 \times$ for all 9 stations on 30 January, 13 February, and 27 February 1998. These dates represent the beginning, middle and end of the Heterocapsa triquetra bloom during the spatially intensive study.

Analysis of historical data to establish annual patterns of runoff, temperature, copepod abundance, and chl a. The monthly runoff for the major coastal North Carolina rivers and streams was estimated by averaging the mean monthly flow rates for the Neuse River measured at the US Geological Survey station (02089500), Kinston, NC (351' N, $\left.77^{\circ} 35^{\prime} \mathrm{W}\right)$, from 1930 to 1998 (Fig. 2). The Neuse River was chosen because it has a drainage basin of $6972 \mathrm{~km}^{2}$ and is representative of the major rivers and streams entering North Carolina estuaries. 

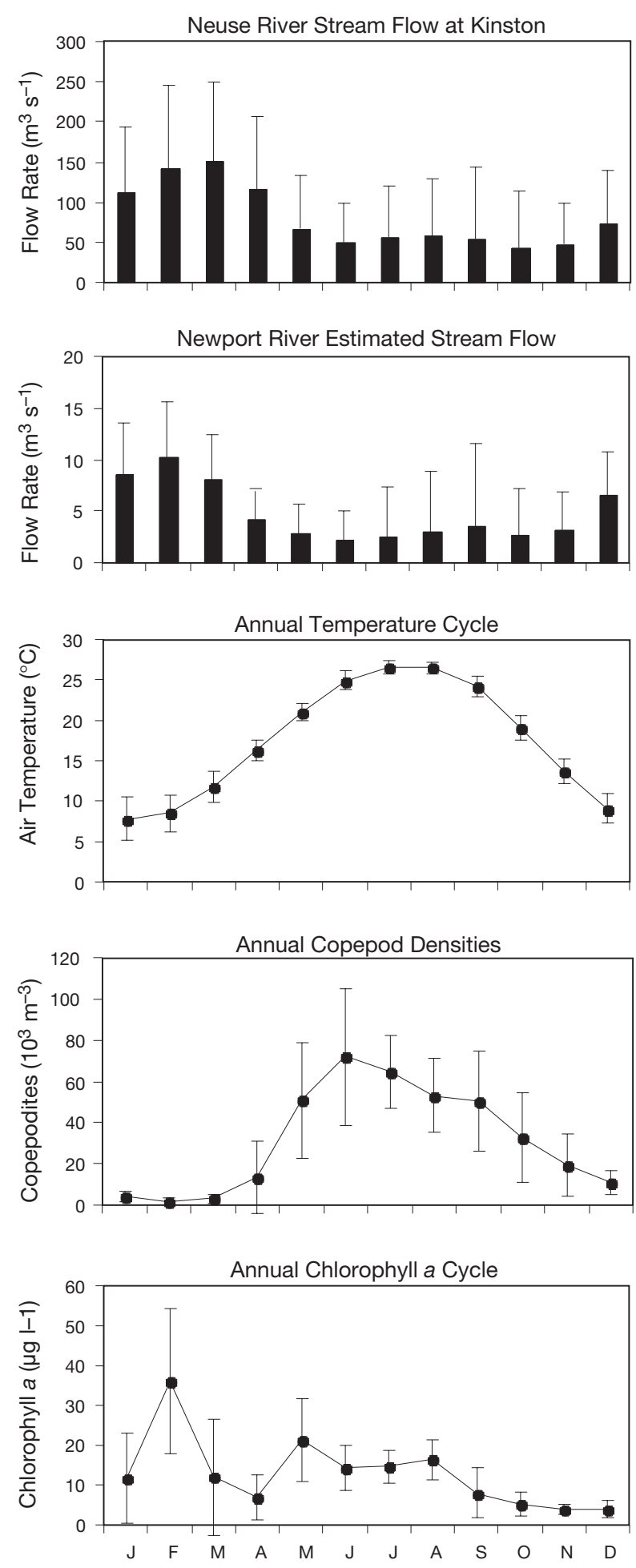

Fig. 2. The mean monthly values $\pm \mathrm{SD}$ for stream flow $\left(\mathrm{m}^{-3} \mathrm{~s}^{-1}\right)$ for the Neuse River at Kinston, North Carolina, from 1930 to 1998, estimated mean monthly flow of the Newport River, air temperature from 1930 to 1998, copepod densities from data in Fulton (1982), and chl a concentrations from studies of the middle portion of the Newport River estuary (Thayer 1971, Pfaender \& Paerl 1984, Litaker et al. 1987, 1993, and present study)
Unfortunately, no flow rate monitoring stations are located on the Newport River, which supplies the major freshwater input into the Newport River estuary. Monthly runoff values were therefore estimated using a program written by Albrecht (Stone et al. 1971) and based on work by Thornthwaite \& Mather $(1955,1957)$. Both mean monthly rainfall and temperatures are required inputs for this model, and those data were available from 1946 to 1998 for Cherry Point and Morehead City, NC. These 2 locations are on opposite sides of the Newport River drainage basin. Flow rates calculated for each of the 2 sites were averaged to estimate the runoff over the entire drainage basin (Fig. 2). The Newport River estuary is representative of the smaller sub-estuaries located along the coast and sounds of North Carolina that receive input from small localized watersheds. The average monthly runoff pattern in these smaller watersheds can vary slightly from those of the major river basins due to a greater influence of localized differences in rainfall.

The annual temperature cycle was determined by averaging mean monthly temperature from 1950 to 1998 (Fig. 2). The mean monthly abundances of copepods in the Newport River estuary were calculated by averaging data for a $3 \mathrm{yr}$ period presented in Fulton (1982) and expressed as copepodites $\times 10^{3} \mathrm{~m}^{-3}$ (Fig. 2). The annual pattern of chl $a$ in the middle to upper estuary was determined by averaging the chl a data for each month taken from Thayer (1971), Pfaender \& Paerl (1984), and Litaker et al. (1987, 1993), as well as the values measured in these studies.

\section{RESULTS}

Prevailing air temperatures were at, or near, the annual low during each of the 3 studies (Figs. 2, 3 \& 4). These cold temperatures reduced evapotranspiration rates to the lowest point of the year. Strong, well-organized frontal systems moved through the study area at regular 3 to $4 \mathrm{~d}$ intervals as evidenced by low pressure waves accompanied by precipitation (Fig. 3). As a consequence, runoff following the rainfall events was higher than at other times of the year (Fig. 2) and provided maximal loading of inorganic $\mathrm{NO}_{2}{ }^{-}, \mathrm{NO}_{3}{ }^{-}, \mathrm{NH}_{4}{ }^{+}$, and $\mathrm{PO}_{4}{ }^{3-}$ into the Newport River estuary during January and February. In the time-intensive studies (1982 and 1983), sampling was done from a fixed point. Increased runoff was indicated by a drop in mean salinity through time, and an increase in nutrients as the lower salinity, higher nutrient water moved past the sampling site (Fig. 4). Nutrients were taken up rapidly upon entering the estuary (Figs. $3 \& 4$ ). The only exception to this was observed during the spatially intensive study for one period in early March when the $\mathrm{NO}_{3}{ }^{-}$ 

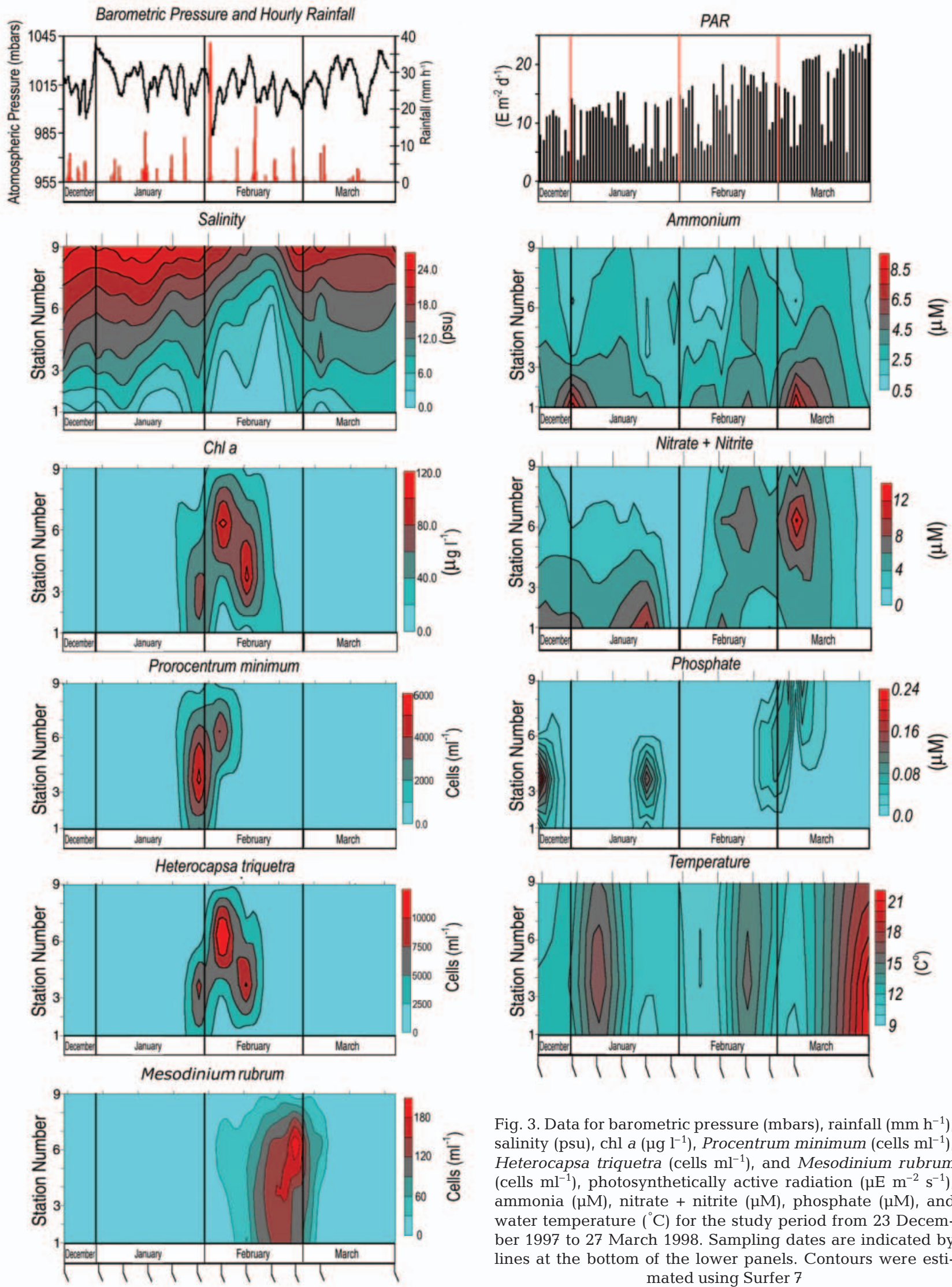

Fig. 3. Data for barometric pressure (mbars), rainfall $\left(\mathrm{mm} \mathrm{h}^{-1}\right)$, salinity (psu), chl a $\left(\mu \mathrm{g} \mathrm{l}^{-1}\right)$, Procentrum minimum (cells ml ${ }^{-1}$ ), Heterocapsa triquetra (cells $\mathrm{ml}^{-1}$ ), and Mesodinium rubrum

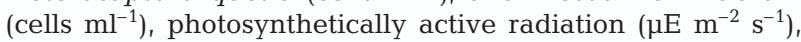
ammonia $(\mu \mathrm{M})$, nitrate + nitrite $(\mu \mathrm{M})$, phosphate $(\mu \mathrm{M})$, and water temperature $\left({ }^{\circ} \mathrm{C}\right)$ for the study period from 23 December 1997 to 27 March 1998. Sampling dates are indicated by lines at the bottom of the lower panels. Contours were estimated using Surfer 7 


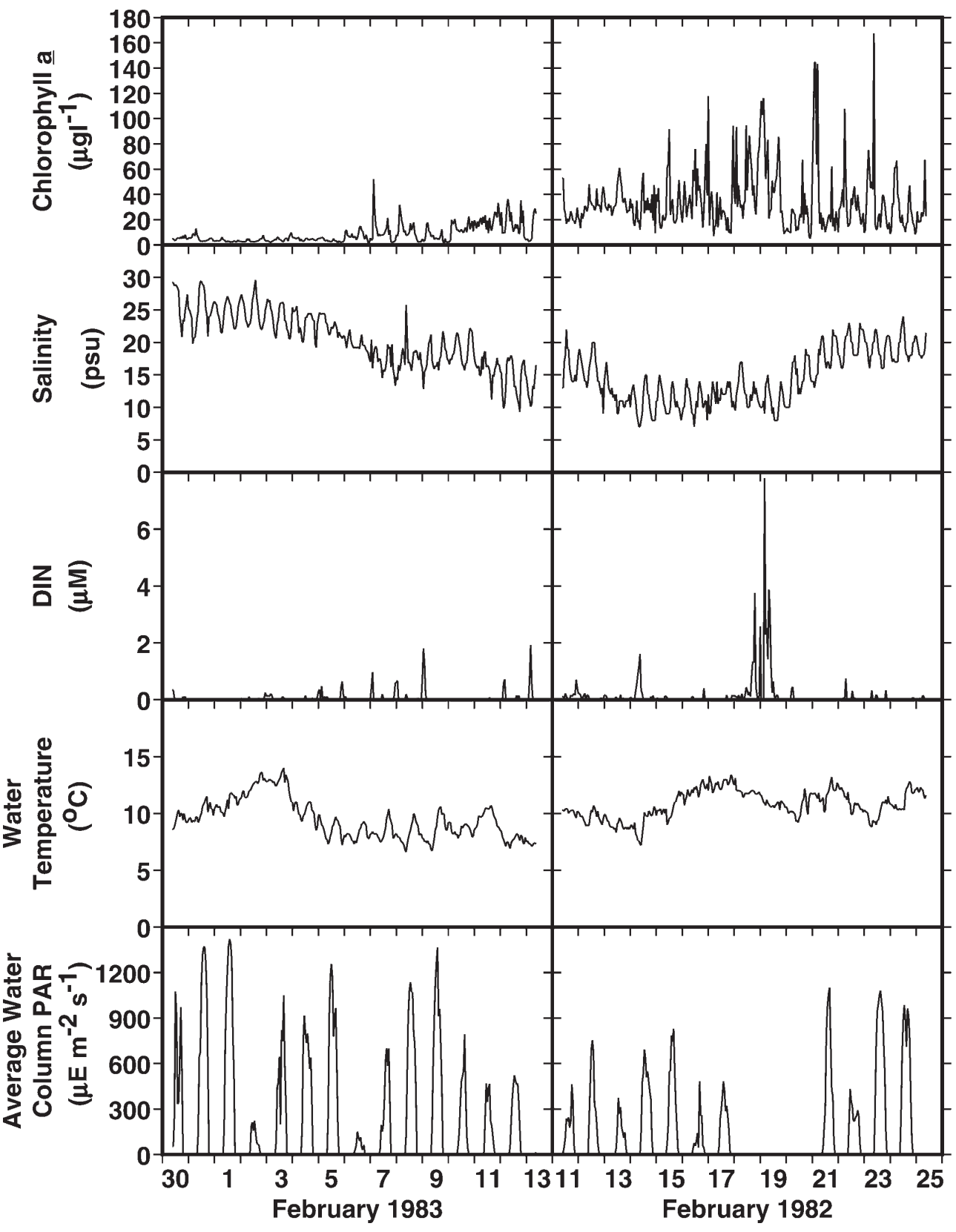

Fig. 4. High-resolution time series measured every hour for 2 wk at Stn 7 for the following variables: chl a $\left(\mu \mathrm{g} \mathrm{l}^{-1}\right)$, salinity (psu), dissolved inorganic nitrogen $\left(\mathrm{NO}_{3}^{-}+\mathrm{NO}_{2}^{-}+\right.$ $\left.\mathrm{NH}_{4}^{+}\right) \mu \mathrm{M}$, water temperature $\left({ }^{\circ} \mathrm{C}\right)$, and average water column photosynthetically active radiation (PAR, $\mu E \mathrm{~m}^{-2} \mathrm{~s}^{-1}$ ). Sampling dates were from 11 February to 25 February 1982 and 30 January to 13 February 1983. The environmental conditions were very similar during late January and February of 1982 and 1983. To show the bloom progression more clearly, the data from the first 2 weeks in February 1983 were plotted before the data from the last 2 weeks in 1982
$+\mathrm{NO}_{2}^{-}$levels were elevated at Stns 6 and 7, which are opposite some of the larger creeks entering the estuary (Figs. 1 \& 3). A small salinity anomaly during that same time period indicates the increased $\mathrm{NO}_{3}{ }^{-}+\mathrm{NO}_{2}{ }^{-}$inputs originated in one or more of the local creeks. Inorganic phosphate concentrations were generally below detection $(<0.2 \mu \mathrm{M})$ during all 3 studies due to a net uptake of $\mathrm{PO}_{4}^{3-}$ by the sediments during winter in North Carolina estuaries (Kuenzler et al. 1977).

In each study, the winter dinoflagellate bloom started in mid-January and was initially dominated by a mixture of Heterocapsa triquetra and Prorocentrum minimum. By early February, the bloom was essentially monospecific for $H$. triquetra (Fig. 3). On average, the $H$. triquetra blooms required approximately 2 to $3 \mathrm{wk}$ to develop. All 3 blooms were preceded by a drop in the average salinity and an increase in inorganic nutrient input (Figs. 3 \& 4). During each study period, the highest chl a concentrations were located in the intermediate salinity section of the estuary. The steep salinity gradient in this mesohaline region represents a frontal zone, where dispersion rates are lower than in the upper and lower 


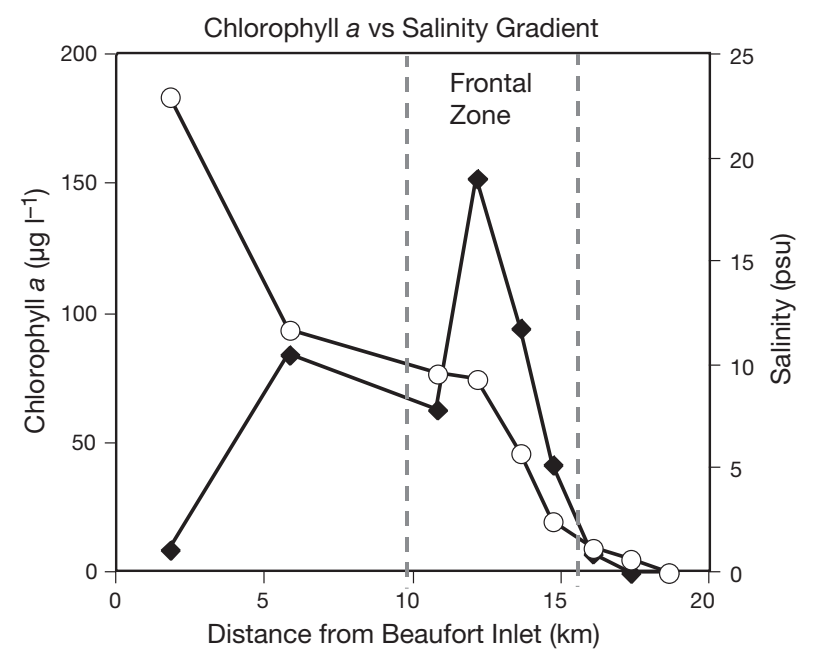

Fig. 5. Chl a $\left(\mu \mathrm{g} \mathrm{l}^{-1}\right)$ and salinity (psu) gradients plotted at each station (Fig. 1) for the transect of the estuary made on 6 February 1998 when the Heterocapsa triquetra bloom was maximally developed. $\bullet=\mathrm{chl} a, \mathrm{O}=$ psu. The frontal zone is bracketed by the 2 vertical lines

portions of the estuary (Figs. $1 \& 5$ ). The relationship between chl a concentrations and the mesohaline structure was evident during all of the 1982 fixed point timeintensive series and in the later part of the 1983 series (Fig. 4). During these periods, chl a levels varied dramatically over a tidal cycle as the chl a maximum moved back and forth past the study site (Figs. 4 \& 5). In each study, the overall bloom progression can be seen as changes in the mean chl a levels with time. Maximal chl a concentrations at the height of the February 1982 bloom were in excess of $100 \mathrm{\mu g} \mathrm{l}^{-1}$ and occurred when salinities were between 7 and 20 psu and at temperatures between 7 and $14^{\circ} \mathrm{C}$. The samples taken during February 1983 represented the pre-bloom and bloom initiation periods and were generally far less than $35 \mu \mathrm{g}$ $\mathrm{l}^{-1}$. During the spatially intensive study (1997 to 1998), chl a concentrations at the height of the $H$. triquetra bloom again exceeded $100 \mu \mathrm{g} \mathrm{chl} \mathrm{ll}^{-1}$ and were located in a mesohaline patch that ranged from 6 to $18 \mathrm{psu}$ (Fig. 3). Chl a levels during the H. triquetra bloom typically exceeded those at any other time of the year (Fig. 2).

Macrozooplankton and microzooplankton abundances were estimated during the 1997 to 1998 study. The dominant macrozooplankton species capable of consuming Heterocapsa triquetra was the copepod Acartia tonsa. A. tonsa densities were estimated to be 642 to 832 individuals $\mathrm{m}^{-3}$ and agree with the wintertime copepod densities of $<1000 \mathrm{~m}^{-3}$ determined previously for the Newport River estuary (Fig. 2; Fulton 1984a,b) and other nearby estuaries (Mallin \& Paerl 1994). Adult female $A$. tonsa isolated at the peak of the $H$. triquetra bloom were used for grazing experiments with ambi- ent concentrations of $H$. triquetra (5 to $7 \times 10^{6} \mathrm{cells} \mathrm{l}^{-1}$ ). Ingestion rates ranged from 605 to $1400 \mathrm{H}$. triquetra cells copepod ${ }^{-1} \mathrm{~h}^{-1}$ and corresponded to filtration rates of 0.09 to $0.24 \mathrm{ml}^{\text {copepod }}{ }^{-1} \mathrm{~h}^{-1}$ (Fig. 6). Using these grazing estimates and a copepod abundance of $\sim 1$ copepod $^{-1}$, A. tonsa could graze approximately $1 \%$ of the $H$. triquetra cells $\mathrm{d}^{-1}$ during the bloom. Decreasing filtration rates with increasing food concentrations indicated the copepods were food-saturated and unlikely to feed continuously at the maximal rate.

The dominant microzooplankton grazers were primarily tintinnids (average $94.3 \pm 6.6 \mu \mathrm{m}$ in length) and oligotrichs (average $38.1 \pm 12.8 \mu \mathrm{m}$ in length). Rotifers were rare. Combined tintinnid and oligotrich densities ranged from $\sim 200$ to 3500 individuals $\mathrm{l}^{-1}$ (Table 1). Tininnids made up $>90 \%$ of the microzooplankton assemblage in most of the samples, though there were a few stations where oligotrichs constituted as much as $80 \%$ of the population. Tintinnid grazing rates on Heterocapsa triquetra can be as high as 15 cells $\mathrm{h}^{-1}$, but are more typically in the range of 0.7 to 3 cells $h^{-1}$ (Stoecker \& Evans 1985). Using the observed densities, and assuming a relatively high ingestion rate of 3 cells $\mathrm{h}^{-1}$, microzooplankton would only be capable of removing between 0.04 and $4 \%$ of the $H$. triquetra bloom population per day.

During the 1997-1998 field study, Heterocapsa triquetra was observed engulfing whole Prorocentrum minimum through an opening in the sulcul region. This ingestion was accompanied by an increase in width and length of the $H$. triquetra cells. The average cell volume changed from $2168 \pm 1192 \mu \mathrm{m}^{3}$ on $16 \mathrm{Jan}$ uary 1998 when the $H$. triquetra bloom was just beginning, to $3432 \pm 1253 \mu^{3}$ on 6 February 1998 at the height of the $H$. triquetra bloom, to $3197 \pm 1262{\mu \mathrm{m}^{3}}^{3}$ on 20 February 1998 when few $P$. minimum cells remained. This increase in volume of $H$. triquetra cells was accompanied by a significant increase in the $\%$ of the population with lengths and widths exceeding $25 \mu \mathrm{m}$

Table 1. Microzooplankton abundances (tintinnids and oligotrich ciliates) $\left(1^{-1}\right)$ measured at 9 sampling stations in the Newport River estuary, North Carolina, on 30 January, 13 February and 27 February 1998

\begin{tabular}{|lrrr|}
\hline Stn & 30 Jan & 13 Feb & 27 Feb \\
\hline 1 & 1300 & 400 & 2160 \\
2 & 380 & 200 & 720 \\
3 & 1480 & 800 & 600 \\
4 & 640 & 480 & 520 \\
5 & 400 & 600 & 280 \\
6 & 800 & 1480 & 1120 \\
7 & 1840 & 2760 & 440 \\
8 & 1160 & 3040 & 680 \\
9 & 1480 & 3360 & 1600 \\
\hline
\end{tabular}




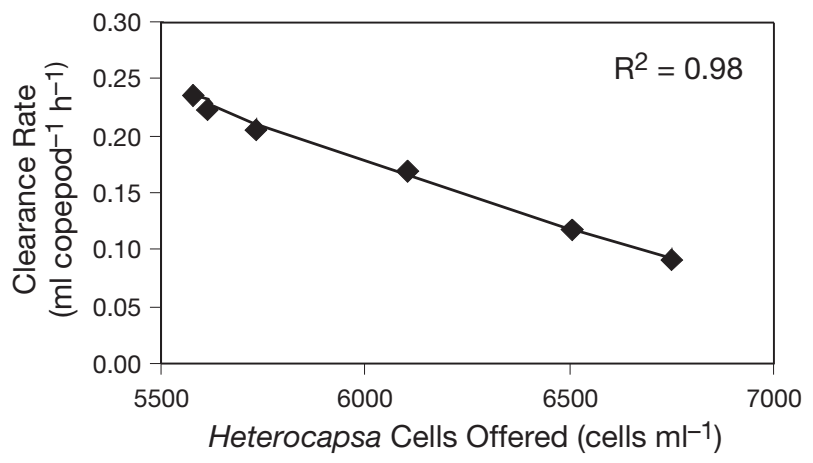

Fig. 6. Clearance rates $\left(\mathrm{ml} \operatorname{copepod}^{-1} \mathrm{~h}^{-1}\right.$ ) of the dominant copepod Acartia tonsa feeding on ambient concentrations of Heterocapsa triquetra from February 1998 in the Newport River estuary, NC

(Fig. 7). The average cell volume increased by $58 \%$ from the pre-bloom to bloom period.

The succession of dominant phytoplankton groups during the winter was estimated by HPLC pigment analysis of samples taken during the 1997-1998 study (Fig. 8). The assemblage was initially dominated by cryptophytes (as indicated by alloxanthin), cyanobacteria (zeaxanthin), and diatoms (fucoxanthin). Starting in late January, a bloom of Prorocentrum minimum and Heterocapsa triquetra began. This dinoflagellate bloom (seen as peridinin in Fig. 8) was initially dominated by $P$. minimum, but by the first week in February, $H$. triquetra was the most abundant species (Fig. 3). The H. triquetra bloom declined in mid- to late February and was followed by a bloom of the ciliate Mesodinium rubrum. The M. rubrum bloom (alloxanthin from endosymbiotic cryptophytes) was followed in mid- to late March by a sudden increase in the diatom population (as indicated by fucoxanthin) as water temperatures began to rise (Figs. $3 \& 8$ ).

\section{DISCUSSION}

Atmospheric forcing in the form of low temperatures and strong frontal systems moving through coastal regions at 3 to $4 \mathrm{~d}$ intervals creates a seasonal niche favorable to Heterocapsa triquetra blooms during winter in temperate estuaries. $H$. triquetra exploits these conditions and out-competes co-occurring species, even though some of the prevailing conditions, such as temperature and light, are suboptimal for phytoplankton growth (Hobbie 1971, Hobbie et al. 1972, Campbell 1973, Kuenzler et al. 1979, Lapennas 1980, Palumbo 1982, Pfaender \& Paerl 1984, Stanley \& Daniel 1985, Litaker et al. 1993, Mallin et al. 1991,
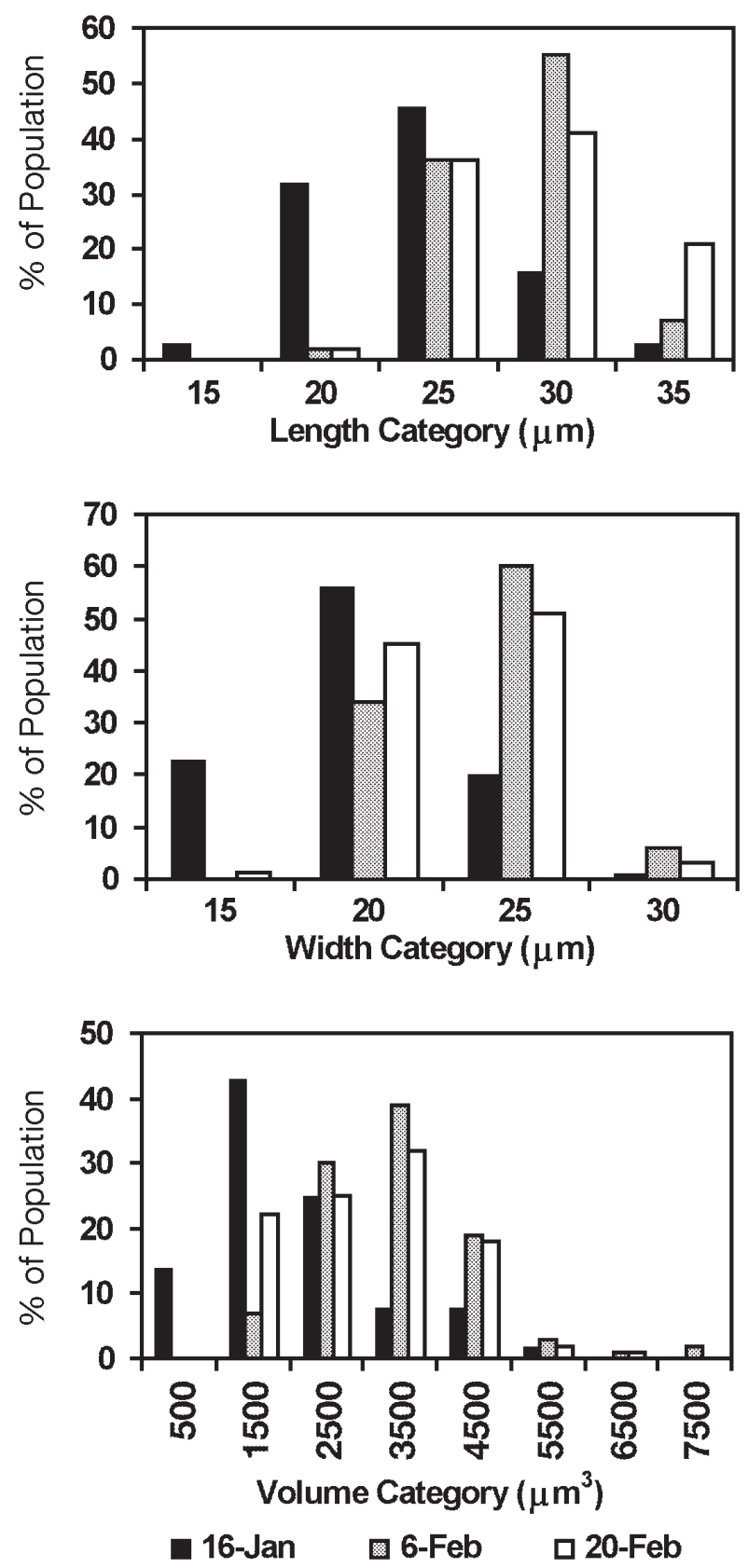

Fig. 7. Heterocapsa triquetra size (length and width) and volume changes during the course of the 1997 to 1998 bloom reflect the shift from phototrophy to mixotrophy. The percentage of the cells in the $H$. triquetra population that were in various width, length, or volume size classes change from 16 January - - (early bloom), 6 February - - (full bloom development), and 20 February 1998 - $\square$ (declining bloom)

Tester et al. 1995). How H. triquetra exploits and responds to the various environmental conditions is discussed below. 

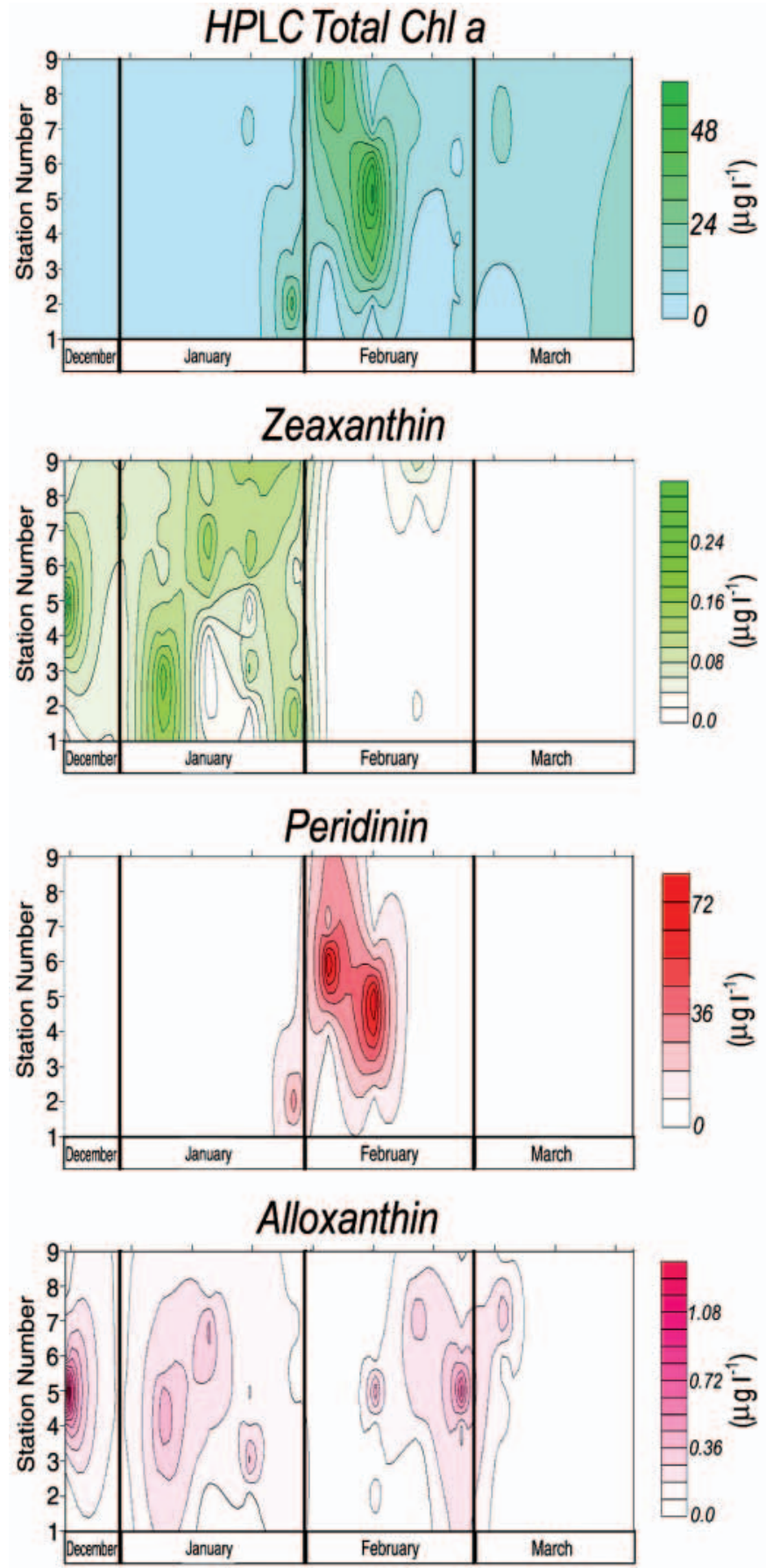

Fucoxanthin

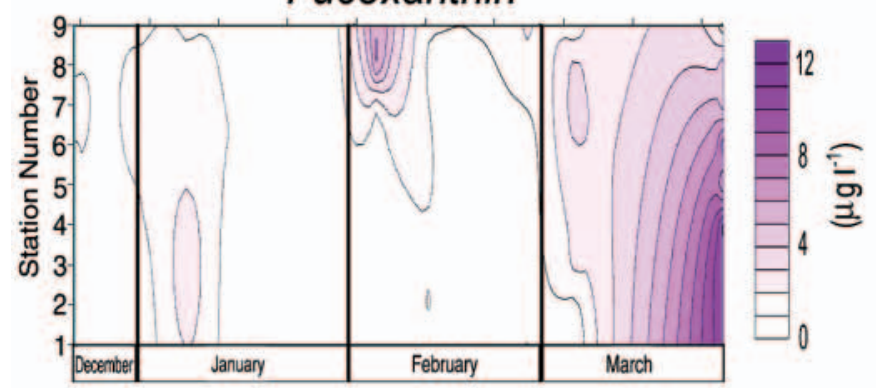

Fig. 8. Succession of dominant phytoplankton groups as determined by HPLC pigment analysis. A total of 109 samples from all the 1997 to 1998 sampling stations were analyzed. The diagnostic pigments included zeaxanthin (cyanobacteria and rhodophytes), peridinin (dinoflagellates), alloxanthin (cryptophytes), and fucoxanthin (contributed by diatoms in this season). The chl a measured by HPLC does not include chlorophyllide or chl $c_{1}, c_{2}$ or $c_{3}$ as does the fluorescence technique used to determine chl $a$ in Fig. 3. This accounts for the difference in the amount of chl a reported (Figs. $3 \&$ 8). However, the patterns of abundance are the same. Pigment concentrations are reported in $\mu \mathrm{g}^{-1}$. Contours were estimated using Surfer 7

Abiotic factors associated with atmospheric forcing and frontal systems (rainfall, light, nutrient inputs, salinity regime, and a runoff-induced frontal zone)

The passage of strong wintertime low pressure systems affects a suite of abiotic factors, including rainfall, nutrient loading, and the prevailing light and salinity regimes. Specifically, as low pressure systems move through the area at 3 to $4 \mathrm{~d}$ intervals, they are associated with regular rainfall events that frequently exceed $50 \mathrm{~mm} \mathrm{~d}^{-1}$ (Fig. 3). These rainfall events coincide with the coldest part of the year $\left(<12^{\circ} \mathrm{C}\right)$, when evapotransporation rates are suppressed (Fig. 2). Even though rain falls equally in the winter and summer, significantly greater runoff occurs in the December to March period than at any other time of the year, excluding hurricane runoff events (Thornwaithe \& Mather 1957, Kuenzler et al. 1977; Fig. 2). Higher runoff elevates nutrient inputs into the system and produces mesohaline conditions throughout much of the estuary (Figs. $3 \& 4$ ).

The passage of low pressure systems is also associated with the increased cloud cover that transiently reduces PAR relative to other times of the year (Litaker et al. this volume). Low PAR in combination with an average $9 \mathrm{~h}$ day length versus a $16 \mathrm{~h}$ day length in midsummer produces the lowest incident light levels of the year. In situ growth rate studies conducted during the 1983 time-intensive study indicate that Heterocapsa triquetra blooms undergo transient day to day light limitation due to increased cloud cover (Litaker et al. 2002). The transient light limitation, however, does not affect bloom formation, indicating that $H$. triquetra is well adapted to low light conditions.

Inputs of nitrate, and to a lesser extent ammonium, appear to be crucial for Heterocapsa triquetra bloom formation (Hobbie et al. 1972, Harrison \& Hobbie 1974, Hobbie \& Smith 1975, Kuenzler et al. 1977, 1979, Lapennas 1980, Stanley \& Daniel 1985, Marshall \& Alden 1990, Mallin et al. 1991). Major runoff events are most frequent from November to March in the North Carolina coastal plain, with maximal runoff and inorganic nutrient inputs occurring in late January to early 
March (Hobbie 1970, Kuenzler et al. 1977; Fig. 2). The H. triquetra blooms tend to occur during the January to early March period. There are, however, occasional years when the winter conditions are unusually warm and dry, and mean daily air temperatures seldom drop below $14^{\circ} \mathrm{C}$. Under these conditions, nutrient inputs are severely curtailed, and the $H$. triquetra bloom either fails to develop or is significantly reduced relative to years when normal runoff occurs (Mallin et al.1991).

Heterocapsa triquetra is physiologically well suited to take advantage of episodic nutrient inputs. It possesses a high $\mathrm{NO}_{3}^{-}$uptake and assimilation capacity and readily takes up $\mathrm{NH}_{4}{ }^{+}$(Harrison 1973). Uptake rates of $\mathrm{NO}_{3}^{-}$are nearly the same in the dark as in the light, even when the cells are nutrient replete (Paasche et al. 1984). H. triquetra is also capable of producing high levels of the extracellular enzyme alkaline phosphatase, allowing it to escape P limitation, which transiently occurs in late winter or early spring in North Carolina estuaries (Thayer 1971, Kuenzler et al. 1979, Rudek et al. 1991).

Heterocapsa triquetra's ability to respond to episodic $\mathrm{N}$ inputs was best documented by the work of Lapennas (1980). She studied the demographic characteristics of over 30 phytoplankton species in the South River estuary, North Carolina ( $34^{\circ} 58^{\prime} \mathrm{N}, 76^{\circ} 35^{\prime} \mathrm{W}$ ), over a $2 \mathrm{yr}$ period. H. triquetra was the most consistent bloomer of any species studied relative to the number of cell divisions needed to reach bloom concentration. It was observed to be the dominant or co-dominant bloom species on 22 occasions during the course of the study. These blooms all occurred in the winter or early spring and were associated with episodic $\mathrm{N}$ inputs following runoff events. On average, 2 to $3 \mathrm{wk}$ and 7 cell divisions were required for $H$. triquetra to reach bloom concentrations, defined as $>50 \mu \mathrm{g} \mathrm{C} \mathrm{l}^{-1}$. A 2 to $3 \mathrm{wk}$ estimate for bloom formation is consistent with the development period observed in this study (Figs. 3 \& 4).

The input of $\mathrm{NO}_{3}^{-}$-rich water, though essential for Heterocapsa triquetra bloom development, is not always sufficient to trigger bloom formation. For example, Harrison (1973) found that salinities decreased and nutrient inputs increased more than a month before $H$. triquetra began to bloom in the Pamlico River estuary. Indeed, $\mathrm{NO}_{3}{ }^{-}$and $\mathrm{NH}_{4}{ }^{+}$inputs are often abundant in November, yet most of the blooms in the Pamlico River (Harrison 1973), South River (Lapennas 1980), and Newport River estuaries are restricted to the early January to March period.

A secondary benefit of the increased runoff is the production of a large mesohaline region in the estuary favorable to growth. Ecologically, Heterocapsa triquetra is often classified as a mesohaline species (Marshall \& Alden 1990), even though it is functionally euryhaline. In culture, $H$. triquetra grows at salinities ranging from $<5$ to $>45 \mathrm{psu}$ (Braarud 1961). H. triquetra's tolerance for a broad range of salinities is further supported by blooms reported from waters with salinities as low as 3 to 4 psu (Hobbie 1971, Hobbie et al. 1972, Kuenzler et al. 1979) and as high as 35 psu (Pieterse \& Van der Post 1967). Under optimal nutrient and light conditions, H. triquetra can achieve $>80 \%$ of maximal growth over a salinity range of 10 to $30 \mathrm{psu}$, with maximal growth occurring between 15 to 20 psu (Braarud \& Pappas 1951). The salinity regimes during this study were generally between 5 to $25 \mathrm{psu}$ and were often within the range reported for optimal growth (Figs. $3 \& 4$ ).

The mesohaline region also represents a frontal zone, where dispersion is reduced relative to the river flushed uppermost portions of the estuary and the tidally flushed lower estuary (Hyle 1976; Figs. 1, 3 \& 6). It was in this region where the Heterocapsa triquetra blooms were found to reach their fullest development (Figs. 3, 4 \& 6). Accumulation of cells in excess of maximal measured growth rates during the 1997-1998 study indicate that $H$. triquetra was physically concentrated in this zone (Litaker et al. this volume). Prorocentrum minimum (= P. mariae-lebouriae) and Mesodinium rubrum, species that were prominent in the mesohaline frontal region before and after the $H$. triquetra bloom, are also known to concentrate along frontal zones with sharp nutriclines or salinity gradients (Tyler \& Seliger 1978, Lindholm \& Mork 1990). In Chesapeake Bay, the accumulation of $H$. triquetra along frontal zones is so pronounced that these blooms are visible on satellite images (Tyler \& Stumpf 1989).

Frontal zones, functionally analogous to those in the Newport River estuary, are also found during the winter in the lateral sub-estuaries of the nearby Albemarle-Pamlico estuary, $\mathrm{NC}\left(35^{\circ} 21^{\prime} \mathrm{N}, 76^{\circ} 32^{\prime} \mathrm{W}\right)$, the largest lagoonal estuary in the US. Blooms in the subestuarine systems form as follows. Heterocapsa triquetra begins to bloom in late January in the uppermost portions of the river systems as winter runoff increases. This runoff generally continues to increase through February and into March. As a consequence, the bloom is pushed into the middle portions of the estuary, where the water entering the main channel of the estuary is relatively fresh and carries large inputs of nutrients (Hobbie 1971, Kuenzler et al. 1979). This nutrient-rich water moves laterally into the peripheral sub-estuaries forcing a limited 2 layer flow circulation with sharply defined salinity gradients (Lapennas 1980, Ustach et al. 1986). H. triquetra is positively phototactic and can migrate in such a way as to exploit these flow regimes to maintain higher than expected population densities (Braruud \& Pappas 1951, Pietrese \& Van der Post 1967, Anderson \& Stolzenbach 1985, Lindholm \& Nummelin 1999). As a result, $H$. triquetra densities commonly exceed $1 \times 10^{8}$ cells $^{-1}$ (chl a con- 
centrations $>250 \mathrm{\mu g} \mathrm{l}^{-1}$ ) in these sub-estuaries. Higher dilution rates in the main channel of the estuary during the same bloom periods limit the corresponding $H$. triquetra cell densities to $\sim 1$ to $5 \times 10^{6} \mathrm{I}^{-1}$ (Hobbie 1971).

Heterocapsa triquetra blooms also can develop as aggregations at stable thermohaline boundaries. These boundaries represent a rich source of inorganic nutrients and have stability properties favorable to $H$. triquetra accumulation. Kononen et al. (2000) for example observed intense blooms of $H$. triquetra localized in 0.2 to $5 \mathrm{~m}$ thick layers 20 to $40 \mathrm{~m}$ below the surface of the water at the entrance to the Gulf of Finland in July 1998. Horizontal patch sizes were generally in the order of $1 \mathrm{~km}$. In every case, the densest concentrations of $H$. triquetra were located at the sharpest part of the nitrocline. Given the strong swimming ability of $H$. triquetra, it was presumed that these bloom concentrations simply represented $H$. triquetra behaviorally aggregating in order to take up nutrients before migrating higher in the water column, where they began active photosynthesis upon exposure to surface illumination.

\section{Low temperatures impose growth limitation on Heterocapsa triquetra and potential grazers (copepods, cilitates, juvenile fish, ctenophores, and benthic filter feeders)}

The primary negative effect imposed on Heterocapsa triquetra by low temperatures is severe growth limitation. $H$. triquetra has a broad temperature growth optimum, with rates $>0.45 \mathrm{~d}^{-1}$ observed from 15 to $26^{\circ} \mathrm{C}$, and maximal rates of between 0.55 and $0.69 \mathrm{~d}^{-1}$ occurring at 19 to $20^{\circ} \mathrm{C}$ (Braarud \& Pappas 1951, Yamochi 1984, Chang \& Carpenter 1988). However, below $15^{\circ} \mathrm{C}$, maximal $H$. triquetra growth rates decline rapidly from $0.4 \mathrm{~d}^{-1}$ at $15^{\circ} \mathrm{C}$, to $0.1 \mathrm{~d}^{-1}$ at $10^{\circ} \mathrm{C}$. Cell division ceases altogether at 4 to $5^{\circ} \mathrm{C}$. The significantly lower growth rate below $15^{\circ} \mathrm{C}$ is also supported by field data. Minimal daily in situ growth rates for $H$. triquetra estimated during the 1983 study varied from 0.02 to $0.14 \mathrm{~d}^{-1}$ over a 7.6 to $12.0^{\circ} \mathrm{C}$ temperature range (Litaker et al. 2002). Each of the observed H. triquetra blooms occurred when average daily water temperatures were generally $<12^{\circ} \mathrm{C}$, and often $<10^{\circ} \mathrm{C}$. Despite the severe growth limitations imposed by these low temperatures, blooms were still able to develop over a 2 to 3 wk period (Figs. 2, $3 \& 4$ ).

In contrast to the negative effects on Heterocapsa triquetra growth, low ambient water temperatures limited macro- and microzooplankton abundance, thereby reducing grazing losses. Both $H$. triquetra's size $(\sim 17 \times$ $26 \mu \mathrm{m})$ and palatability make it an excellent food source for copepods (Uye \& Takamatsu 1990) and many common ciliate species (Gifford 1985). Copepod population densities estimated in the 1997-1998 study were 1000 -fold lower than in the summer, when copepods can remove up to $25 \%$ of the phytoplankton biomass as chl a day ${ }^{-1}$ (Stearns et al. 1987). Approximately $1 \%$ of the $H$. triquetra cells $\mathrm{d}^{-1}$ were grazed by Acartia tonsa, the dominant macrozooplankter present during this study.

There is a parallel argument for reduced microzooplankton grazing during these winter blooms. Microzooplankton grazing rates often exceed those of macrozooplankters, particularly when water temperatures are elevated and the average cell size is $<10 \mu \mathrm{m}$ (Burkhill et al. 1987, Litaker et al. 1988). In contrast, during winter in temperate estuaries, microzooplankton concentrations are generally too low to graze significant numbers of phytoplankton cells, although there are exceptions to this general trend (Verity 1986, Sanders 1987, Baird \& Ulanowicz 1989, Mallin 1991, Kamiyama 1994, 1997, Gallegos \& Jordon 1997). The microzooplankton assemblage measured during the spatially intensive study (1997 to 1998) was dominated by tintinnids and oligotrichs. The tintinnid/oligotrich cell concentrations ranged from $\sim 200$ to 3500 individuals $\mathrm{l}^{-1}$ (Table 1). These population densities, like those of the macrozooplankton grazers, were too low to cause significant gazing losses in the Newport River estuary. Similarly, low grazing losses during dinoflagellate blooms have been reported by Sellner \& Brownlee (1990) in the Chesapeake Bay.

Juvenile Atlantic menhaden Brevortia tyrannus are the only major species of planktivorous fish present in the estuary between December and March, but they are not capable of reducing Heterocapsa triquetra numbers substantially. Menhaden have an unusual life history in that the early larvae feed only on zooplankton, but during metamorphosis increase their capacity to retain smaller phytoplankters. The adults are plantivores and their distribution is positively correlated with the abundance of microflagellates, diatoms, and to a limited extent, dinoflagellates (Friedland et al. 1989). The switch from feeding on zooplankton to becoming filter feeders occurs as the larvae increase in size from about 30 to $45 \mathrm{~mm}$ fork length (FL) (June \& Carlson 1971, Govoni et al. 1983). The average size of menhaden that migrate into the Newport River estuary from offshore between December and early March, however, is between 23 to $30 \mathrm{~mm}$ FL (Warlen 1994). Hence, most of the larval menhaden are too small to be effective filter feeders during the period when the $H$. triquetra bloom occurs. Furthermore, the abundances of menhaden larvae in the Newport River estuary between December and early March is in the order of 7 to 8 per $100 \mathrm{~m}^{3}$ (Warlen 1994), far too low to significantly impact phytoplankton standing stocks. 
Ctenophores were also observed during the study, and were particularly abundant during several weeks of the bloom. However, they, like the juvenile menhaden, are not capable of grazing particles the size of Heterocapsa triquetra either (Stoecker et al. 1987). If anything, grazing by ctenophores on zooplankton would further reduce grazing pressure on $H$. triquetra (Robertson 1983). The only other members of the estuarine community with the potential to remove significant amounts of phytoplankton are benthic filter feeders. However, water temperatures $<12^{\circ} \mathrm{C}$ can severely limit filtration and growth rates, rendering them incapable of removing significant quantities of phytoplankton (Grizzle et al. 2001).

\section{Success strategies: cysts and mixotrophic nutrition}

Resting cysts, keyed to the annual temperature cycle, may be important in controlling the timing of Heterocapsa triquetra bloom formation. Yamochi \& Joh (1986) studied the effects of temperature on the excystment of 7 species of red tide algae found in the sediments of Osaka Bay, including $H$. triquetra. They examined the hypothesis of Anderson \& Wall (1978) that a close correlation exists between germination of benthic cysts and initiation of certain dinoflagellate blooms. At incubation temperatures $<10^{\circ} \mathrm{C}, H$. triquetra germinated in 56 to $94 \%$ of the sediment samples. Very few of the samples incubated $>20^{\circ} \mathrm{C}$ contained $H$. triquetra, and none of the samples incubated $>23^{\circ} \mathrm{C}$ produced vegetative cultures. The appearance of $H$. triquetra was attributed to the germination of benthic cysts and not the growth of vegetative cells sequestered in the sediments. During the same period, $H$. triquetra was abundant in the water column only at temperatures $<15^{\circ} \mathrm{C}$ as is commonly the case in the Newport River estuary. Whether a similar excystment occurs in the Newport River estuary is unknown because cyst densities there were not measured. However, $H$. triquetra hypnocysts have been reported for the nearby South River (Lapennas 1980) and Gales Creek estuaries (Campbell 1973). Evolution of cyst germination timed to the annual temperature minimum, or slightly higher, would allow $H$. triquetra to take advantage of the recurrent wintertime conditions formed by atmospheric forcing in many temperate estuaries. Temperature regulated excystment could also account for the fact that blooms often lag the initial input of nutrients into the estuary by more than a month.

Laboratory studies have shown that Heterocapsa triquetra grew phototrophically when sufficient inorganic nutrients were available, but fed mixotrophically when nutrients became limiting (Legrand et al. 1998).
The switch to mixotrophy was characterized by a 61 to $64 \%$ increase in average cell volume. In contrast nutrient-starved cells in the absence of available phytoplankton prey actually decreased in size. Mixotrophic feeding provided a means for nutrient-depleted cells to meet their $\mathrm{N}$ and $\mathrm{P}$ demands. In the 1997-1998 study, $H$. triquetra began consuming Prorocentrum minimum cells once the bloom became established. The switch to mixotrophy was accompanied by a $58 \%$ increase in cell volume. Nutrient depleted $H$. triquetra cells ingest 0.2 to 0.4 algal cells $\mathrm{d}^{-1}$ in laboratory studies, implying grazing rates in the field were significant when $H$. triquetra cell numbers exceeded 2000 cells $\mathrm{ml}^{-1}$. Interestingly, laboratory studies of $P$. minimum, the primary food source available to $H$. triquetra during the bloom, showed that this species also switched to mixotrophic consumption of co-occurring phytoplankton when nutrients became limiting (Stoecker et al. 1997). The consumption of dinoflagellate blooms by other dinoflagellates may therefore be relatively common in estuarine and near shore regions (Jeong 1999, Jeong et al. 1999). An ancillary benefit of mixotrophy is the reduction of co-occurring species that compete for similar resources (Thingstad et al. 1996).

Changes in the phytoplankton community structure reported during other Heterocapsa triquetra blooms also suggested that this species frequently resorted to mixotrophy. At the start of these blooms, H. triquetra almost always co-occurred with 1 or more of the following dinoflagellate species: Alexandrium tamarense, Ceratium fusus, Gonyaulax spinifera, Gonyaulax sp., Karoldinium micrum (= Gymnodinium galatheanum), Gyrodinium aureolum, Katodinium rotundatum, Prorocentrum micans, Prorocentrum minimum, Protoperidinium sp., or Scrippsiella trochoidea (Marshall 1967, Pieterse \& Van Der Post 1967, Anderson et al. 1983, Stoecker et al. 1983, Anderson \& Stolzenbach 1985, Lee \& Yoo 1990, Marshall \& Alden 1990, Mallin 1994, Akselman 1996). The association between $H$. triquetra and $P$. minimum was particularly strong. As these blooms progressed, however, the community often changed with $H$. triquetra becoming numerically dominant.

\section{Fate of the Heterocapsa triquetra bloom?}

The decline of a phytoplankton bloom can be caused by either single or concomitant factors including dilution, grazing or disease. The only data in this study from a bloom decline comes from the 1997 to 1998 period. In this instance, washout appeared to be the major factor responsible for the bloom decline. A large drop in salinity, associated with a significant runoff event, coincided with a sharp decline in Heterocapsa 
triquetra cell numbers (Fig. 3). Besides reducing H. triquetra cell numbers, the runoff event supplied new nutrients to the system. $H$. triquetra, however, did not respond with renewed growth (Figs. $3 \&$ 8). One possibility for $H$. triquetra's lack of response is that the cells were already senescing after a period of nutrient depletion indicated by the switch to mixotrophy.

Studies of other Heterocapsa triquetra blooms from different North Carolina estuaries indicated that these blooms all declined abruptly. Often this decline occurred by mid- to late February, with blooms seldom lasting beyond mid-March or the first week in April as water temperatures reached 17 to $19^{\circ} \mathrm{C}$ (Hobbie 1971, Hobbie et al. 1972, Carpenter 1973, Kuenzler et al. 1979, Tester et al. 1995). Though the general period when the blooms declined was fairly similar, the causes appeared variable. Sometimes the bloom decline was directly correlated with decreased inorganic $\mathrm{N}$ input. This typically occurred when runoff declined as evapotranspiration rates accelerated with warming air temperatures. Indeed, in extremely dry years, when the nutrient input dropped below a critical threshold, the $H$. triquetra blooms failed to materialize (Mallin 1994).

Other studies, however, have documented the demise of Heterocapsa triquetra blooms while nutrient and temperature conditions were apparently still conducive to growth (Mallin et al. 1991, Rudek et al. 1991). Since these declines are not likely due to grazing as discussed above, there must be other reasons for $\mathrm{H}$. triquetra bloom termination. Typically the decline of a dinoflagellate bloom, when environmental conditions are favorable for growth, is generally attributed to either cyst formation (Anderson et al. 1983) or disease (Wommack \& Colwell 2000). There is evidence that $H$. triquetra has cysts that germinate at low temperatures, which may help initiate bloom formation. However, whether $H$. triquetra is capable of forming cysts when conditions are still favorable for growth is not known.

The role of viruses or bacteria in limiting Heterocapsa triquetra blooms is similarly unknown. However, there is mounting evidence suggesting that common viral and bacterial diseases can quickly spread through a phytoplankton population causing rapid cell death (Wommack \& Colwell 2000). To the extent that this is true, these pathogens will play a critical role in the overall structuring and functioning of marine food webs (Proctor 1997, Guixa-Boixereu et al. 1999).

\section{Fate of the carbon fixed by the Heterocapsa triquetra bloom?}

The Heterocapsa triquetra bloom represents large quantities of highly utilizable carbon. Up to $50 \%$ of the annual C fixation in North Carolina estuaries can be attributed to the winter dinoflagellate blooms dominated by $H$. triquetra (Paerl et al. 1998, Pinckney et al. 1998). Studies in the Chesapeake Bay indicate that most of the $\mathrm{C}$ from $H$. triquetra and other dinoflagellate blooms was metabolized before reaching the sediments (Sellner et al. 1991, 1993). Given that macroand microzooplankton grazing was negligible during the bloom, it was unlikely that the large amount of C contained in the winter dinoflagellate bloom was transferred directly to higher trophic levels. Instead C, $\mathrm{N}$, and $\mathrm{P}$ were probably being cycled indirectly to higher trophic levels through the microbial loop (Riemann et al. 2000).

\section{Heterocapsa triquetra in the context of seasonal succession}

The succession of the winter phytoplankton community was evident from HPLC pigment analyses (Fig. 8). The assemblage was dominated by cryptophytes and picoplanktonic cyanobacteria from late December to late January, when chl a levels were $<10 \mu \mathrm{g} \mathrm{l}^{-1}$. Salinities were generally declining during this period, indicating increased nutrient inputs. Cryptophytes in particular increased during mid-January. Similar increases in cryptophyte abundance in response to runoff events have also been documented for the nearby Neuse River estuary (Mallin et al. 1991). The cryptophyte community was then succeeded by a dinoflagellate community dominated by Prorocentrum minimum and to a lesser extent Heterocapsa triquetra in late January (Figs. 3 \& 8). Recent studies have shown that $P$. minimum feeds mixotrophically, and has a preference for cryptophyte species (Stoecker et al. 1997). This raises the possibility that some of the decline in the cryptophyte assemblage was due to mixotrophic consumption as the $P$. minimum bloom developed.

An even more intense Heterocapsa triquetra bloom succeeded the Prorocentrum minimum bloom. This combined $H$. triquetra- $P$. minimum bloom is representative of the common wintertime dinoflagellate-dominated blooms that occur sometime between January and March. These blooms are a persistent feature of North Carolina estuaries (Pinckney et al. 1998). Evidence suggests that the decline in $P$. minimum numbers was due to the mixotrophic consumption by $\mathrm{H}$. triquetra. The decline in $H$. triquetra abundance, in turn, was attributed to washout caused by a major runoff event (Fig. 3).

The next plankton species to dominate was the cilitate Mesodinium rubrum. This organism has an unusual nutritional ecology. It ingests cryptophytes and utilizes their chloroplasts to achieve extraordinarily 
high rates of photosynthesis (Barber et al. 1969, Smith \& Barber 1979, Gustafson et al. 2000). Presumably an assemblage of free-living cryptophytes benefited from the nutrient input during the washout event and began to grow (Figs. $3 \&$ 8). Otherwise the increasing $M$. rubrum population would not have been able to acquire its requisite cryptophytes. The close correspondence between the cryptophyte pigment alloxanthin and the cell counts of $M$. rubrum indicated that a majority of the cryptophyte pigment was contained within M. rubrum.

In mid-March, the wintertime cryptophyte and dinoflagellate assemblages were succeeded by the spring diatom bloom, indicated by fucoxanthin (Fig. 8). This increase in diatom biomass was associated with the rapid increase in water temperatures that occurred in late March and appears to be a regular occurrence in North Carolina estuaries (Tester et al. 1995, Pinckney et al. 1998). The beginning of the annual increase in copepod abundances also coincides with this rapid increase in ambient temperatures (Fig. 2).

\section{Heterocapsa triquetra: a dynamic model for harmful algal blooms (HABs)}

While Heterocapsa triquetra is not a toxic algal species, many of the seasonal and environmental factors that allow it to form dense $\left(>10^{6} \mathrm{l}^{-1}\right)$, nearly monospecific blooms in estuaries and coastal regions throughout the world (Kim 1997, Kononen et al. 1999, Lindholm \& Nummelin 1999) are important to most harmful species as well. H. triquetra blooms are nutrient-driven and are identified with seasonal coastal dynamics similar to those proposed to promote the formation of Alexandrium tamaranse blooms in NE US waters (Keafer \& Anderson 1993). Further, there is mounting evidence that nutrient inputs are required to sustain the extraordinarily high cell densities found during Karenia brevis (= Gymnodinium breve) blooms in the near shore waters of the eastern Gulf of Mexico (Vargo et al. 2000). K. brevis, like $H$. triquetra, is a superior nutrient competitor, capable of taking up both inorganic and organic nutrients (Steidinger et al. 1998). Like $H$. triquetra, K. brevis effectively adapts to low light conditions, so neither low ambient light conditions nor self-shading during a bloom significantly affects its growth. The $H$. triquetra bloom is driven by meteorological forcing events that alter the physical environment of the estuary in a manner favorable for bloom formation. Similar environmental forcing or circulation patterns are associated with the development of other HAB blooms including Pseudo-nitzschia spp. (Hickey 2000), A. tamaranse (Anderson et al. 2000) and $K$. brevis (Steidinger et al. 1993, Tester \& Stei- dinger 1997). Finally, $H$. triquetra exploits seasonal niches to avoid grazing losses that would inhibit bloom formation. Other HAB species accomplish this by mucus production or being unpalatable (Turner \& Tester 1997). Understanding the common conditions conducive to harmful algal bloom formation, as well as how individual harmful species in a successional series respond to a recurrent suite of biotic and abiotic factors, will provide greater predictive power as to when and where blooms are likely to occur.

\section{SUMMARY}

Late winter blooms of Heterocapsa triquetra in temperate estuaries are usually associated with low ambient water temperatures and atmospheric forcing events that produce extensive runoff. This runoff delivers inorganic nutrients to the estuary, reduces salinities, and creates frontal zones in the mesohaline portions of the estuary. Low pressure waves associated with the rain events that occur every 3 to 4 days also bring increased cloud cover that transiently light-limits $H$. triquetra growth. The low ambient water temperatures also suppress the growth of both macro- and microzooplankton grazers whose populations are at an annual low when $H$. triquetra blooms. $H$. triquetra effectively utilizes the nutrient inputs, mesohaline conditions, low grazing pressure, and favorable hydrodynamic conditions to bloom, despite suboptimal temperature and light conditions. As nutrients become depleted, $H$. triquetra switches to a mixotrophic feeding mode and begins to consume co-occurring algae to meet its nutritional needs. Mixotrophy has the added benefit of reducing competing algae.

Despite low levels of Heterocapsa triquetra being found throughout most of the year, there are several studies that indicate that $H$. triquetra has evolved a cyst that excysts at temperatures $<10^{\circ} \mathrm{C}$. Low temperature excystment would provide a seed population at exactly the right time to exploit the late winter conditions. A number of factors including dilution from high runoff, senescence, encystment, and viral diseases could be responsible for the decline of $H$. triquetra blooms. Evidence suggests that of all these possibilities, washout from a high runoff event in mid-February was primarily responsible for the 1997 to 1998 bloom decline (Fig. 3). The wintertime microzooplankton and macrozooplankton grazing rates were insufficient to significantly influence the succession of phytoplankton species. Hence, mixotrophic feeding relationships between the various phytoplankton groups, particularly dinoflagellates, may greatly influence species composition and the succession of various phytoplankton species during winter in temperate 
region estuaries. The dynamics of $H$. triquetra blooms serve as a general model for dinoflagellate bloom development including harmful or toxic species.

Acknowledgements. We thank 3 anonymous reviewers for superb critical reviews of this manuscript. Dr. Bill Kirby-Smith provided the flat bottom boat that made the shallow water sampling possible in the 1998 study. B. Peirels and Dr. H. Paerl provided the 1998 light, temperature, barometric pressure, and PAR data from the weather station located at the Institute of Marine Sciences in Morehead City, NC. M. Guo and B. Peirels ran the nutrient samples for the 1998 study. S. Varnam counted the phytoplankton samples and B. Yonish provided graphics support. D. Millie kindly allowed us (P.A.T.) the use of his HPLC facility. B. Butler provided editorial assistance. Funding for this study was provided by the NSF (Grant No. OCE-81-13328) and the National Center for Coastal Ocean Science, National Ocean Service, NOAA, ECOHAB Contribution No. 42. The use of brand names does not imply endorsement by the US Government. The US Government has the right to retain a nonexclusive royalty-free license in and to any copyright covering this paper. This paper is dedicated to Sue Kenney.

\section{LITERATURE CITED}

Akselman R (1996) Ecological studies in San Jorge Gulf and adjacent areas (SW Atlantic). Phytoplankton distribution, abundance and seasonal variation in relation to physicochemical factors and hydrology. Facultad de Ciencias Exactas y Naturales, Buenos Aires

Ambler J (1982) Influence of natural particle diets on egg laying and hatching success of Acartia tonsa in East Lagoon, Galveston, Texas. PhD thesis, Texas A\&M University, College Station, TX

Anderson D, Stolzenbach K (1985) Selective retention of two dinoflagellates in a well-mixed estuarine embayment: the importance of diel vertical migration and surface avoidance. Mar Ecol Prog Ser 25:39-50

Anderson D, Wall D (1978) Potential importance of benthic cysts of Gonyaulax tamarensis and G. excavata in initiating toxic dinoflagellate blooms. J Phycol 14:224-234

Anderson D, Chisholm S, Watras C (1983) Importance of life cycle events in the population dynamics of Gonyaulax tamarensis. Mar Biol 76:179-189

Anderson DM, Keafer BA, Churchill JH, Geyer WR, Signell RP (2000) Alexandrium fundyense blooms in the western Gulf of Maine. Symposium on harmful marine algae in the US, December 4-9, 2000. Marine Biological Laboratory, Woods Hole, MA, p 16 (Abstract)

Baird D, Ulanowicz R (1989) The seasonal dynamics of the Chesapeake Bay ecosystem. Ecol Monogr 59:329-364

Barber R, White A, Siegelman H (1969) Evidence for a cryptomonad symbiont in the ciliate, Cyclotrichium meunieri. J Phycol 5:86-88

Braarud T (1961) Cultivation of marine organisms as a means of understanding environmental influences on populations. In: Sears M (ed) Oceanography. No. 67. American Association for the Advancement of Science, Washington, DC, p 271-298

Braarud T (1962) Species distributions in marine phytoplankton. J Oceanogr Soc Jpn 20:628-649

Braarud T, Pappas I (1951) Experimental studies on the dinoflagellate Peridinium triquetrum (Ehrb.) Lebour Avhand- linger Utgitt Ar Det Norske Videnskaps-Akademi I Oslo 1. Mat. Naturv. Klasse 2:1-23

Burkhill P, Mantoura R, Llewellyn C, Owens N (1987) Microzooplankton grazing and selectivity of phytoplankton in coastal waters. Mar Biol 93:581-590

Campbell P (1973) Studies on brackish water phytoplankton. Sea Grant Publication UNC-SG-73-07, University of North Carolina p 407

Carpenter EJ (1973) Brackish-water phytoplankton response to temperature elevation. Estuar Coast Mar Sci 1:37-44

Chang J, Carpenter E (1988) Species-specific phytoplankton growth rates via diel DNA synthesis cycles. II. DNA quantification and model verification in the dinoflagellate Heterocapsa triquetra. Mar Ecol Prog Ser 44:287-298

Friedland K, Arhenholz D, Guthrie J (1989) Influence of plankton on distribution patterns of the filter-feeder Brevoortia tyrannus (Pisces: Clupeidae). Mar Ecol Prog Ser 54:1-11

Frost R (1972) Effects of size and concentration of food particles on the feeding behavior of the marine planktonic copepod Calanus pacificus. Limnol Oceanogr 17:805-815

Fulton R (1982) Predation and the organization of an estuarine copepod community. PhD thesis, Duke University, Durham, NC

Fulton R (1984a) Distribution and community structure of estuarine copepods. Estuaries 7:38-50

Fulton R (1984b) Predation, production and organization of an estuarine copepod community. J Plankton Res 6:399-415

Gallegos C, Jordan T (1997) Seasonal progression of factors limiting phytoplankton pigment biomass in the Rhode River estuary, Maryland (USA). I. Controls on phytoplankton growth. Mar Ecol Prog Ser 161:185-198

Gifford D (1985) Laboratory culture of marine planktonic oligotrichs (Ciliophora, Oligotrichida). Mar Ecol Prog Ser 23:257-267

Govoni J, Hoss D, Chester A (1983) Comparative feeding of three species of larval fishes in the northern Gulf of Mexico: Brevoortia patronus, Leiostomus xanthurus, and Micropogonias undulatus. Mar Ecol Prog Ser 13:189-199

Grizzle RE, Bricelj VM, Shumway SE (2002) Physiological ecology. In: Kraeuter JN, Castagna M (eds) Biology of the hard clam, Mercenaria mercenaria, Chapter 7. Developments in agriculture and fisheries science 31. Elsevier Science Publishers, New York, p 305-382

Guillard R (1973) Division rates. In: Stein J (ed) Phycological methods. Cambridge University Press, Cambridge, p 289-311

Guixa-Boixereu N, Lysnes K, Pedros-Alio C (1999) Viral lysis and bacterivory during a phytoplankton bloom in a coastal water microcosm. Appl Environ Microbiol 65:1949-58

Gustafson DE, Stoecker DK, Johnson MD, Van-Heukelem WF, Sneider K (2000) Cryptophyte algae are robbed of their organelles by the marine ciliate Mesodinium rubrum. Nature 405:1049-1052

Harrison W (1973) Nitrate reductase activity during a dinoflagellate bloom. Limnol Oceanogr 18:457-465

Harrison W, Hobbie J (1974) Nitrogen budget of a North Carolina estuary. WRRI Report No. 86, UNC Water Resources Research Institute, Raleigh, NC

Hickey BM (2000) HABS-related physical oceanography on the US West Coast. Symposium on harmful marine algae in the US. December 4-9, 2000. Marine Biological Laboratory, Woods Hole, MA, p 36 (Abstract)

Hillebrand H, Dürselen C, Kirschtel D, Pollingher U, Zohary T (1999) Biovolume calculation for pelagic and benthic microalgae. J Phycol 35:403-424

Hobbie J (1970) Hydrography of the Pamlico River estuary, 
NC. WRRI Report No. 39, UNC Water Resources Research Institute, Raleigh, NC

Hobbie J (1971) Phytoplankton species and populations in the Pamlico River estuary of North Carolina. WRRI Report No. 56, UNC Water Resources Research Institute, Raleigh, NC

Hobbie J, Smith N (1975) Nutrients in the Neuse River estuary, North Carolina. Sea Grant Publication UNC-SG-7521. University of North Carolina, p 183

Hobbie J, Copeland B, Harrison W (1972) Nutrients in the Pamlico River estuary, NC 1969-1971. WRRI Report No. 76, UNC Water Resources Research Institute, Raleigh, NC

Hyle RA III (1976) Fishes of the Newport River estuary, North Carolina, their composition, seasonality and community structure, 1970-1972. PhD thesis, University of North Carolina

Jeffrey S, Vesk M (1997) Introduction to marine phytoplankton and their pigment signatures. In: Jeffrey S, Mantoura $\mathrm{R}$, Wright $\mathrm{S}$ (eds) Phytoplankton pigments in oceanography. UNESCO Publishing, Paris, p 37-84

Jeong HJ (1999) The ecological roles of heterotrophic dinoflagellates in marine planktonic community. J Eukaryot Microbiol 46:390-396

Jeong HJ, Shim JH, Kim JS, Park JY, Lee CW, Lee Y (1999) Feeding by the mixotrophic thecate dinoflagellate Fragilidium $\mathrm{cf}$ mexicanum on red-tide and toxic dinoflagellates. Mar Ecol Prog Ser 176:263-277

June F, Carlson F (1971) Food of young Atlantic menhaden, Brevoortia tyrannus, in relation to metamorphosis. Fish Bull 68:493-512

Kamiyama T (1994) The impact of grazing by microzooplankton in northern Hiroshima Bay, the Seto Inland Seam, Japan. Mar Biol 119:77-88

Kamiyama T (1997) Effects of phytoplankton abundance on excystment of tintinnid ciliates from marine sediments. J Oceanogr 53:299-302

Keafer BA, Anderson DM (1993) Use of remotely-sensed sea surface temperatures in studies of Alexandrium tamarense bloom dynamics. In: Smayda TJ, Shimizu Y (eds) Toxic phytoplankton blooms in the sea. Elsevier Science Publishers, Amsterdam, p 763-768

Kim HG (1997) Recent harmful algal blooms and mitigation strategies in Korea. Ocean Res 19:185-192

Kim HG, Park JS, Lee SG (1990) Coastal algal blooms caused by the cyst-forming dinoflagellates. Bull Korean Fish Soc 23:468-474

Kononen K, Huttunen M, Kanoshina I, Laanemets J, Moisander P, Pavelson J (1999) Spatial and temporal variability of a dinoflagellate-cyanobacterium community under a complex hydrodynamical influence: a case study at the entrance to the Gulf of Finland. Mar Ecol Prog Ser 186: $43-57$

Kononen K, Gentien P, Huttula T, Huttunen M, Laanemets J, Pavelson J, Stips A (2000) Deep chlorophyll maximum created by Heterocapsa triquetra Ehrenberg at the entrance to the Gulf Of Finland, Baltic Sea. 9th Int Conf Harmful Algal Blooms. 7-11 February 2000, Hobart, Tasmania, p 153 (Abstract)

Koroleff I (1970) Direct determination of ammonia in natural waters as indophenol blue: information on techniques and methods for sea water analysis. J Cons Cons Int Explor Mer 3:19-22

Kuenzler E, Mullholland PJ, Ruley L, Sniffen R (1977) Water quality in North Carolina coastal plain streams and effects of channelization. WRRI Report No. 127, UNC Water Resources Research Institute, Raleigh, NC

Kuenzler E, Stanley D, Koenings J (1979) Nutrient kinetics of phytoplankton in the Pamlico River, North Carolina. WRRI
Report No. 139, UNC Water Resources Research Institute, Raleigh, NC

Lapennas P (1980) Demographic patterns of phytoplankton species in a variable estuary. PhD thesis, Duke University, Durham, NC

Lee JB, Yoo KL (1990) Dynamics and seasonal succession of dinoflagellate community in Masan Bay, Korea. J Oceanol Soc Korea 25:106-116

Lee WJ, Kim HG, Park YT, Seong HK (1990) The role of marine bacteria in the dinoflagellate bloom. 1. Distribution of marine bacteria and dinoflagellate in Chinhae Bay. Bull Korean Fish Soc 23:303-309

Legrand C, Granéli E, Carlsson P (1998) Induced phagotrophy in the photosynthetic dinoflagellate Heterocapsa triquetra. Aquat Microb Ecol 15:65-75

Lindholm T, Mork AC (1990) Depth maxima of Mesodinium rubrum (Lohmann) Hamburger \& Buddenbrock-examples from a stratified Baltic Sea Inlet. Sarsia 75:53-64

Lindholm T, Nummelin C (1999) Red tide of the dinoflagellate Heterocapsa triquetra (Dinophyta) in a ferry mixed coastal inlet. Hydrobiologia 393:245-251

Litaker W (1986) Dynamics of a well-mixed estuary. PhD thesis, Duke University, Durham, NC

Litaker W, Duke CS, Kenney BE, Ramus J (1987) Short-term environmental variability and phytoplankton abundances in a shallow tidal estuary. I. Winter and summer. Mar Biol 96:115-121

Litaker W, Duke C, Kenney B, Ramus J (1988) Diel chl a and phaeopigment cycles in a shallow tidal estuary: potential role of microzooplankton grazing. Mar Ecol Prog Ser 47: $259-270$

Litaker W, Duke C, Kenney B, Ramus J (1993) Short-term environmental variability and phytoplankton abundances in a shallow tidal estuary. II. Spring and fall. Mar Ecol Prog Ser 94:141-154

Litaker RW, Warner VE, Rhyne C, Duke CS, Kenney BE, Ramus J, Tester PA (2002) Effect of diel and interday variations in light on the cell division pattern and in situ growth rates of the bloom-forming dinoflagellate Heterocapsa triquetra. Mar Ecol Prog Ser 232:63-74

Lund JWG, Kipling C, Le Cren E (1958) The inverted microscope method of estimating algal numbers and the statistical basis of estimations by counting. Hydrobiologia 11:143-170

Mallin M (1991) Zooplankton abundance and community structure in a mesohaline North Carolina estuary. Estuaries 14:481-488

Mallin M (1994) Phytoplankton ecology of North Carolina estuaries. Estuaries 17:561-574

Mallin M, Paerl H (1994) Planktonic trophic transfer in an estuary: seasonal, diel, and community structure effects. Ecology 75:2168-2184

Mallin M, Paerl H, Rudek J (1991) Seasonal phytoplankton composition, productivity and biomass in the Neuse River estuary, North Carolina. Estuar Coast Shelf Sci 32:609-623

Mallin M, Paerl H, Rudek J, Bates P (1993) Regulation of estuarine primary production by watershed rainfall and river flow. Mar Ecol Prog Ser 93:199-203

Marshall H (1967a) Plankton in James River estuary, Virginia. I. Phytoplankton in Willoughby Bay and Hampton Roads. Chesapeake Sci 8:90-101

Marshall H (1967b) Plankton in James River estuary, Virginia II. Phytoplankton in Elizabeth River. Virginia J Sci 18:105-109

Marshall H (1980) Seasonal phytoplankton composition in the lower Chesapeake Bay and Old Plantation Creek, Cape Charles, Virginia. Estuaries 3:207-216

Marshall H, Alden R (1990) A comparison of phytoplankton 
assemblages and environmental relationships in three estuarine rivers of the lower Chesapeake Bay. Estuaries 13:287-300

Mulford R (1972) Phytoplankton of Chesapeake Bay. Chesapeake Sci 13:S74-S81

Paasche E, Bryceson I, Tangen K (1984) Interspecific variation in dark nitrogen uptake by dinoflagellates. J Phycol 20: $394-401$

Paerl H, Pinckney J, Fear J, Peierls B (1998) Ecosystem responses to internal and watershed organic matter loading: consequences for hypoxia in the eutrophic. Neuse River estuary, North Carolina, USA. Mar Ecol Prog Ser 166: $17-25$

Palumbo A (1982) Dynamics of bacterioplankton in the Newport River estuary. PhD thesis, North Carolina State University, Raleigh, NC

Parsons T, Maita Y, Lalli C (1984) A manual of chemical methods for seawater analysis. Pergamon Press, Fairview Park

Pfaender F, Paerl H (1984) Particulate-dissolved partitioning and fate of toxic organics in estuarine environments. Final Report No. NA81 RAD 0025, Office of Marine Pollution Assessment, NOAA

Pierce R, Turner J (1994) Plankton studies in Buzzards Bay, Massachusetts, USA, III. Dinoflagellates, 1987 to 1988. Mar Ecol Prog Ser 112:225-234

Pieterse F, Van der Post D (1967) Oceanographical conditions associated with red-tides and fish mortalities in the Walvis Bay region. Mar Res Lab Invest Rep (S-W Africa) 14:1-129

Pinckney J, Paerl H, Harrington M, Howe K (1998) Annual cycles of phytoplankton community-structure and bloom dynamics in the Neuse River Estuary, North Carolina. Mar Biol 131:371-381

Proctor L (1997) Advances in the study of marine viruses. Microsc Res Tech 37:136-61

Riemann L, Steward GF, Azam F (2000) Dynamics of bacterial community composition and activity during a mesocosm diatom bloom. Appl Environ Microbiol 66:578-587

Riley GA (1957) Phytoplankton of the north central Sargasso Sea. Limnol Oceanogr 2:252-270

Robertson J (1983) Predation by estuarine zooplankton on tintinnid ciliates. Estuar Coast Shelf Sci 16:27-36

Rudek J, Paerl H, Mallin M, Bates P (1991) Seasonal and hydrological control of phytoplankton nutrient limitation in the lower Neuse River Estuary, North Carolina. Mar Ecol Prog Ser 75:133-142

Sanders R (1987) Tintinnids and other microzooplanktonseasonal distributions and relationships to resources and hydrography in a Maine estuary. J Plankton Res 9:65-77

Sellner K, Brownlee D (1990) Dinoflagellate-microzooplankton interactions in Chesapeake Bay. In: Graneli E, Sundstrom B, Edler L, Anderson D (eds) Toxic marine phytoplankton. Elsevier Science Publishers, New York, p 221-226

Sellner K, Lacouture R, Cibik S, Brinkley A, Brownlee S (1991) Importance of a winter dinoflagellate microflagellate bloom in the Patuxent River, Maryland, USA estuary. Estuar Coast Shelf Sci 32:27-42

Sellner K, Sawangwong P, Dawson R, Boynton W, Kemp W, Garber J (1993) Fate of dinoflagellates in Chesapeake Bay: is sedimentation likely? In: Smayda T, Shimizu Y (eds) Toxic phytoplankton blooms in the sea. Elsevier Science Publishers, Amsterdam, p 825-830

Smith W, Barber R (1979) A carbon budget for the autotrophic ciliate Mesodinium rubrum. J Phycol 15:27-33

Stanley DW, Daniel DA (1985) Seasonal phytoplankton density and biomass changes in South Creek, North Carolina. J Elisha Mitchell Sci Soc 101:130-141
Stearns D, Litaker W, Rosenberg G (1987) Impacts of zooplankton grazing and excretion on short-interval fluctuations in chlorophyll $a$ and nitrogen concentrations in a well-mixed estuary. Estuar Coast Shelf Sci 24:305-325

Steidinger KA, Vargo GA, Tester PA, Tomas CR (1998) Bloom dynamics and physiology of Gymnodinium breve with emphasis on the Gulf of Mexico. In: Anderson DM, Cembella AD, Hallegraeff GM (eds) Physiological ecology of harmful algal blooms. NATO ASI (Advanced Sciences Institutes) Series, Vol. G41. Springer-Verlag, Berlin, p 134-153

Stoecker D (1984) Particle production by planktonic ciliates. Limnol Oceanogr 29:930-940

Stoecker D, Evans G (1985) Effects of protozoan herbivory and carnivory in microzooplankton food web. Mar Ecol Prog Ser 25:159-167

Stoecker D, Davis L, Provan A (1983) Growth of Flavella sp. (Ciliata: Tintinnina) and other microzooplankters in cages incubated in situ and comparison to growth in vitro. Mar Biol 75:293-302

Stoecker D, Verity P, Michaels A, Davis L (1987) Feeding by larval and post-larval ctenophores on microzooplankton. J Plankton Res 9:667-682

Stoecker D, Li A, Coats D, Gustafson D, Nannen M (1997) Mixotrophy in the dinoflagellate Prorocentrum minimum. Mar Ecol Prog Ser 152:1-12

Stone L, Albrecht J, Yoshioka G (1971) Computer programs for the climatic water balance. Publications in Climatology, Vol XXIV, No. 3. CW Thornthwaite Associates, Laboratory of Climatology, Elmer, NJ

Surfer 7 (1999) Surfer user's guide contouring and 3D surface mapping for scientists and engineers. Golden Software, Golden, CO

Tester P, Steidinger K (1997) Gymnodinium breve red tide blooms: initiation, transport, and consequences of surface circulation. Limnol Oceanogr 42:1039-1051

Tester P, Geesey M, Guo C, Paerl H, Millie D (1995) Evaluating phytoplankton dynamics in the Newport River Estuary (North Carolina, USA) by HPLC-derived pigment profiles. Mar Ecol Prog Ser 124:237-245

Thayer G (1971) Phytoplankton production and the distribution of nutrients in a shallow unstratified estuarine system near Beaufort, NC. Chesapeake Sci 12:240-253

Thingstad T, Havskum H, Garde K, Riemann B (1996) On the strategy of 'eating your competitor': a mathematical analysis of algal mixotrophy. Ecology 77:2108-2118

Thornthwaite C, Mather J (1955) The water balance. Publ Climatol 8:1-86

Thornthwaite C, Mather J (1957) Instructions and tables for computing potential evapotranspiration and the water balance. Publ Climatol 10:185-311

Turner JT, Tester PA (1997) Toxic marine phytoplankton, zooplankton grazers, and pelagic food webs. Limnol Oceanogr 42:1203-1214

Tyler MA, Seliger HH (1978) Annual subsurface transport of a red tide dinoflagellate to its bloom area: water circulation patterns and organism distributions in the Chesapeake Bay. Limnol Oceanogr 23(2):227-246

Tyler MA, Stumpf RP (1989) Feasibility of using satellites for detection of kinetics of small phytoplankton blooms in estuaries: tidal and migrational effects. Remote Sens Environ 27:233-250

Ustach J, Kirby-Smith W, Barber R (1986) Effect of watershed modification on a small coastal plain estuary. In: Wolfe D (ed) Estuarine variability. Academic Press, New York, p 177-192

Uye S, Takamatsu K (1990) Feeding interactions between 
planktonic copepods and red-tide flagellates from Japanese coastal waters. Mar Ecol Prog Ser 59:97-107

Vargo G, Heil C, Spence D, Neely MB and 5 others (2000) An overview of the ECOHAB-Florida region on the west Florida shelf: basic hydrographic information and its relationship to a Gymnodinium breve red tide. 9th Int Conf Harmful Algal Blooms, 7-11 February, Hobart, Tasmania, p 242 (Abstract)

Verity P (1986) Grazing of phototrophic nanoplankton by microzooplankton in Narragansett Bay. Mar Ecol Prog Ser 29:105-115

Warlen S (1994) Spawning time and recruitment dynamics of larval Atlantic menhaden, Brevoortia tyrannus, into a North Carolina estuary. Fish Bull 92:420-433

Editorial responsibility: Yves Collos (Contributing Editor), Montpellier, France
Wiebe P (1988) Functional regression equations for zooplankton displacement volume, wet weight, dry weight, and carbon: a correction. Fish Bull 86:833-835

Wommack K, Colwell R (2000) Virioplankton: viruses in aquatic ecosystems. Microbiol Mol Biol Rev 64:69-114

Yamochi S (1984) Effects of temperature on the growth of six species of red-tide flagellates occurring in Osaka Bay. Bull Plankton Soc Jpn 31:15-22

Yamochi S, Joh H (1986) Effects of temperature on the vegetative cell liberation of seven species of red-tide algae from the bottom mud in Osaka Bay. J Oceanogr Soc Jpn 42:266-275

Yentsch CS, Menzel DW (1963) A method for the determination of phytoplankton chlorophyll and phaeophytin by fluorescence. Deep-Sea Res 10:221-231

Submitted: August 13, 2000; Accepted: August 20, 2001 Proofs received from author(s): April 10, 2002 